\title{
Evaluation of protein pattern changes in roots and leaves of Zea mays plants in response to nitrate availability by two-dimensional gel electrophoresis analysis Bhakti Prinsi ${ }^{1}$, Alfredo S Negri ${ }^{1}$, Paolo Pesaresi ${ }^{2}$, Maurizio Cocucci ${ }^{1}$ and Luca Espen*1
}

Address: ${ }^{1}$ Dipartimento di Produzione Vegetale, University of Milan, via Celoria 2, I-20133 Milano, Italy and ${ }^{2}$ Dipartimento di Produzione Vegetale, University of Milan c/o Fondazione Parco Tecnologico Padano, via Einstein - Località Cascina Codazza, I-26900 Lodi, Italy

Email: Bhakti Prinsi - bhakti.prinsi@unimi.it; Alfredo S Negri - alfredo.negri@unimi.it; Paolo Pesaresi - paolo.pesaresi@unimi.it; Maurizio Cocucci - maurizio.cocucci@unimi.it; Luca Espen* - luca.espen@unimi.it

* Corresponding author

Published: 23 August 2009

BMC Plant Biology 2009, 9:1 I3 doi:10.1 I86/147I-2229-9-II3
Received: 2 April 2009

Accepted: 23 August 2009

This article is available from: http://www.biomedcentral.com/I47I-2229/9/II3

(c) 2009 Prinsi et al; licensee BioMed Central Ltd.

This is an Open Access article distributed under the terms of the Creative Commons Attribution License (http://creativecommons.org/licenses/by/2.0), which permits unrestricted use, distribution, and reproduction in any medium, provided the original work is properly cited.

\begin{abstract}
Background: Nitrogen nutrition is one of the major factors that limit growth and production of crop plants. It affects many processes, such as development, architecture, flowering, senescence and photosynthesis. Although the improvement in technologies for protein study and the widening of gene sequences have made possible the study of the plant proteomes, only limited information on proteome changes occurring in response to nitrogen amount are available up to now. In this work, two-dimensional gel electrophoresis (2-DE) has been used to investigate the protein changes induced by $\mathrm{NO}_{3}{ }^{-}$concentration in both roots and leaves of maize (Zea mays $\mathrm{L}$.) plants. Moreover, in order to better evaluate the proteomic results, some biochemical and physiological parameters were measured.
\end{abstract}

Results: Through 2-DE analysis, 20 and 18 spots that significantly changed their amount at least two folds in response to nitrate addition to the growth medium of starved maize plants were found in roots and leaves, respectively. Most of these spots were identified by Liquid Chromatography Electrospray lonization Tandem Mass Spectrometry (LC-ESI-MS/MS). In roots, many of these changes were referred to enzymes involved in nitrate assimilation and in metabolic pathways implicated in the balance of the energy and redox status of the cell, among which the pentose phosphate pathway. In leaves, most of the characterized proteins were related to regulation of photosynthesis. Moreover, the up-accumulation of lipoxygenase 10 indicated that the leaf response to a high availability of nitrate may also involve a modification in lipid metabolism.

Finally, this proteomic approach suggested that the nutritional status of the plant may affect two different posttranslational modifications of phosphoenolpyruvate carboxylase (PEPCase) consisting in monoubiquitination and phosphorylation in roots and leaves, respectively.

Conclusion: This work provides a first characterization of the proteome changes that occur in response to nitrate availability in leaves and roots of maize plants. According to previous studies, the work confirms the relationship between nitrogen and carbon metabolisms and it rises some intriguing questions, concerning the possible role of $\mathrm{NO}$ and lipoxygenase 10 in roots and leaves, respectively. Although further studies will be necessary, this proteomic analysis underlines the central role of post-translational events in modulating pivotal enzymes, such as PEPCase. 


\section{Background}

Under field conditions, nitrogen nutrition is one of the major factors that influence plant growth $[1,2]$. The availability of this nutrient affects many processes of the plant, among which development, architecture, flowering, senescence, photosynthesis and photosynthates allocation [1-7].

The low bio-availability of nitrogen in the pedosphere with respect to the request of the crops has spawned a dramatic increase in fertilization that has detrimental consequences on environment such as water eutrophication and increase in $\mathrm{NH}_{3}$ and $\mathrm{N}_{2} \mathrm{O}$ in the atmosphere $[6,8]$.

Moreover, this side-effect is severe in the case of cereals, which account for $70 \%$ of food production worldwide. Indeed, in these crops the grain yield is strictly correlated with $\mathrm{N}$ supply but the use efficiency is not higher than $50 \%[9]$.

Because of the economical relevance, the feasibility to combine extensive physiological, agronomic and genetic studies as well as the high metabolic efficiency of $\mathrm{C}_{4}$ plants, maize (Zea mays L.) was proposed as the model species to study $\mathrm{N}$ nutrition in cereals [10].

Among nitrogen inorganic molecules, nitrate is the predominant form in agricultural soils, where it can reach concentrations three or more orders of magnitude higher than in natural soils $[11,12]$.

In root cells, the uptake of this mineral nutrient involves inducible and constitutive transport systems [13]. Both systems mediate the transport of the anion by $\mathrm{H}^{+}$symport mechanisms [14-19] sustained by $\mathrm{H}^{+}$-ATPase [20-22].

The first step of nitrate assimilation, that occurs in both roots and shoots, involves its reduction to ammonia by nitrate reductase (NR) and nitrite reductase (NiR) enzymes, followed by transfer of ammonia to $\alpha$-chetoglutaric acid by the action of glutamine synthetase (GS) and glutamate synthase (GOGAT) [23-25]. The pathway is induced in the presence of nitrate and shows many connections with other cellular traits, among which carbohydrate and amino acid metabolism, redox status and $\mathrm{pH}$ homeostasis $[6,19,26,27]$. Hence, nitrate and carbon metabolisms appear strictly linked and co-regulated, both locally and at long distance for the reciprocal root/leaf control, in response to the nutritional status of the plant and environmental stimuli $[3,6,26-28]$.

In the last years, some transcriptomic analyses have been conducted to shed light on the molecular basis of these regulatory mechanisms. Wang and co-workers studied the transcriptomic changes occurring after exposure to low and high nitrate concentrations in whole plants of Arabidopsis thaliana, by means of microarray and RNA gel blot analysis [29]. Besides the genes already known to be regulated by the presence of nitrate, the authors found new candidate genes encoding for regulatory proteins such as a MYB transcription factor, a calcium antiporter, putative protein kinases and several metabolic enzymes. Another study conducted by Scheible and co-workers [7] reports a comparative transcriptomic analysis of Arabidopsis thaliana seedlings grown in sterile liquid culture under nitrogen-limiting and nitrogen-replete conditions by using Affymetrix ATH1 arrays and (RT)-PCR. The authors observed that the response to nitrogen availability involved a deep reprogramming of primary and secondary metabolisms. These data well describe the complexity of nitrogen pathway as well as the direct and/or indirect consequences that nitrogen availability exerts on the whole metabolism of the plant.

Starting from these results it should be now desirable to deepen the knowledge about the changes at translational and post-translational levels in response to nitrogen availability. In the last decade, the improvement in technologies for protein study and the widening of gene sequences made possible the study of the plant proteomes [30-34].

In this context, the availability of a large EST assembly and the efforts in sequencing maize genome [35] contributed to improve the use of maize, as highlighted by a large number of studies conducted on this species, among which the proteomic characterizations of leaf [36], of chloroplasts in bundle sheath and mesophyll cells [37] and of pericycle cells of primary roots [38].

At the present time, to the best of our knowledge no studies on nitrogen nutrition in maize were conducted by this approach. The only two proteomic works regarding this issue in cereals are based on the use of 2-DE to compare the leaves [39] and the roots [40] of two wheat varieties exposed to different levels of nitrogen. These works pointed out some significant differences, correlated to $\mathrm{N}$ availability during the plant growth, in the protein profiles of both organs.

In order to obtain further information, in this work we investigated protein accumulation changes induced by nitrate in both roots and leaves of Zea mays plants. The attention was focused on the changes in the pattern of protein soluble fractions caused by the addition of $10 \mathrm{mM}$ nitrate to the hydroponic solution, after a period in which the plants were grown in the absence of nitrogen. Firstly, the changes of some biochemical parameters were measured to describe the physiological response occurring after nitrate addition and were used to define the sampling time for proteomic analysis. These experiments led to 
compare the proteomes of plants previously grown for 17 days in absence of nitrogen and incubated for further 30 $\mathrm{h}$ without the nutrient or in the presence of $10 \mathrm{mM}$ nitrate. Through 2-DE and LC-ESI-MS/MS analyses a first characterization of the proteome changes occurring in maize plants in response to an increase in nitrate availability was obtained. The results show how many of these changes were related to enzymes of the nitrate assimilation or metabolic pathways strictly linked to it (e.g. pentose phosphate pathway and photosynthesis), but also reveal new proteins that may play a role in the nitrate responses.

\section{Results and discussion}

\section{Experimental design and biochemical parameters}

The aim of this work was to apply a proteomic approach to study the changes in protein patterns of root and leaf organs of maize plants in the first phase of exposure to high availability of nitrate, comparable to agricultural conditions, after a growth period under nitrogen starvation. This is a typical condition in which the addition of nitrate induces an increase in uptake and assimilation of this nutrient $[5,28]$.

The need for a simultaneous analysis of the root and the leaf organs of starved plants, with completely developed but not stressed leaf apparatus, led to the definition of the experimental design showed in Figure 1. Briefly, seedlings were transferred into a hydroponic system after 3 days of germination and grown for further 14 days in a solution deprived of nitrogen. After that, at the beginning of the light period $\left(\mathrm{T}_{0}\right)$, some plants were maintained in the same nutritional condition (control, C) whereas others were transferred in a nutrient solution containing $10 \mathrm{mM}$ $\mathrm{NO}_{3}{ }^{-}(\mathrm{N})$. In order to define the sampling time for pro-

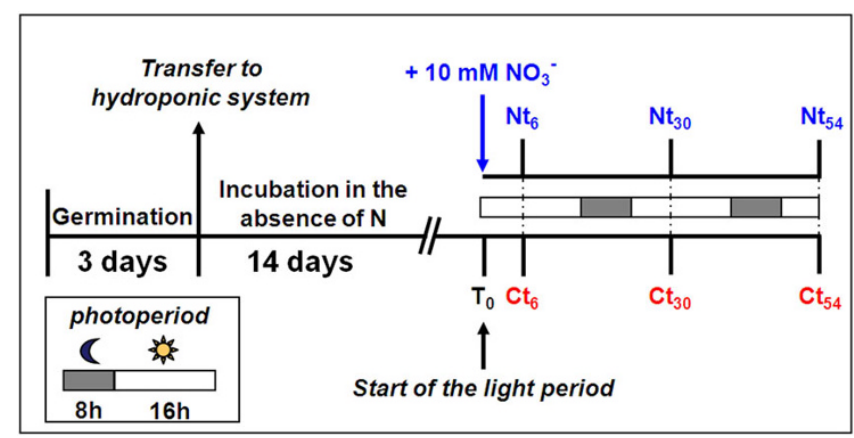

Figure I

Experimental design. Zea mays seeds were germinated in the dark. After 3 days, the seedlings were transferred in a hydroponic system and grown for 14 days in the absence of nitrogen $\left(T_{0}\right)$, afterwards the plants were incubated for further $54 \mathrm{~h}$ in the same condition (Control, C) or in the presence of $10 \mathrm{mM} \mathrm{KNO}_{3}(\mathrm{~N})$. For details see the methods section. teomic analysis, the changes of biochemical parameters in response to $\mathrm{NO}_{3}{ }^{-}$were firstly evaluated. Roots and leaves were collected at $\mathrm{T}_{0}$ time and after 6,30 and $54 \mathrm{~h}$ of nitrate exposure.

At these sampling times, the plants achieved the developmental stage corresponding to the complete expansion of the third leaf (pictures of harvested plants are showed in Additional file 1). The qualitative comparison between the $\mathrm{C}$ and $\mathrm{N}$ plants revealed some morphological differences. In particular, while the plants appeared very similar at the $\mathrm{T}_{0}$ sampling time, after $30 \mathrm{~h}$ the expansion of the fourth leaf was slightly more evident in $\mathrm{N}$ plants with respect to the $\mathrm{C}$ ones. This trend was more pronounced at $54 \mathrm{~h}$ and, only in C plants, was accompanied by the comparison of faint yellow areas in the leaf blades. In the tested conditions, no significant differences were observed in root system.

In order to characterize the physiological status of the plants, the changes in nitrate content and NR activity (Figure 2) as well as the levels of proteins, amino acids, reducing sugars, sucrose and chlorophyll were evaluated (Figure $3)$.

In roots and leaves of starved plants, both nitrate and NR activity were undetectable. After the addition of the nutrient to hydroponic solution the levels of nitrate progressively increased in plant tissues, reaching a level of 32.6 and $10.3 \mu \mathrm{mol}$ of $\mathrm{NO}_{3} \mathrm{~g}^{-1} \mathrm{FW}$ after $54 \mathrm{~h}$ in roots and leaves respectively (Figure 2A). A parallel dramatic increase of NR activity was measured until the $30^{\text {th }} \mathrm{h}$ of $\mathrm{NO}_{3}-$ exposure, while at the longest time considered (54 h) a decreased activity was observed (Figure 2B). This trend was more evident in the roots in which a more rapid and large availability of nitrate took place. The total protein levels did not change significantly in all the conditions tested (Figure $3 \mathrm{~A}$ and $3 \mathrm{~B}$ ), while a sharp increase in free amino acids was detected in both organs after nitrate addition (Figure 3C and 3D). Moreover, the levels of amino acids were higher in the leaves than in the roots. Although many factors are involved in the overall amino acid levels, these results may suggest a contribution of translocation of nitrogen compounds between the two organs. Nitrate exposure also induced a decrease in reducing sugars in both organs (Figure $3 \mathrm{E}$ and Figure $3 \mathrm{~F}$ ), while only in the roots of the plants exposed for $54 \mathrm{~h}$ to $10 \mathrm{mM}$ $\mathrm{NO}_{3}{ }^{-}$a drop of sucrose took place (Figure $3 \mathrm{G}$ ).

Taken together, these results well describe the induction trend of $\mathrm{NO}_{3}$ - assimilation pathway, as suggested by the increase of NR activity and amino acids accompanied by the consequent decrease of reducing sugars, the main source of carbon skeletons [41]. In roots, where photosynthesis cannot satisfy this request and/or the demand of 


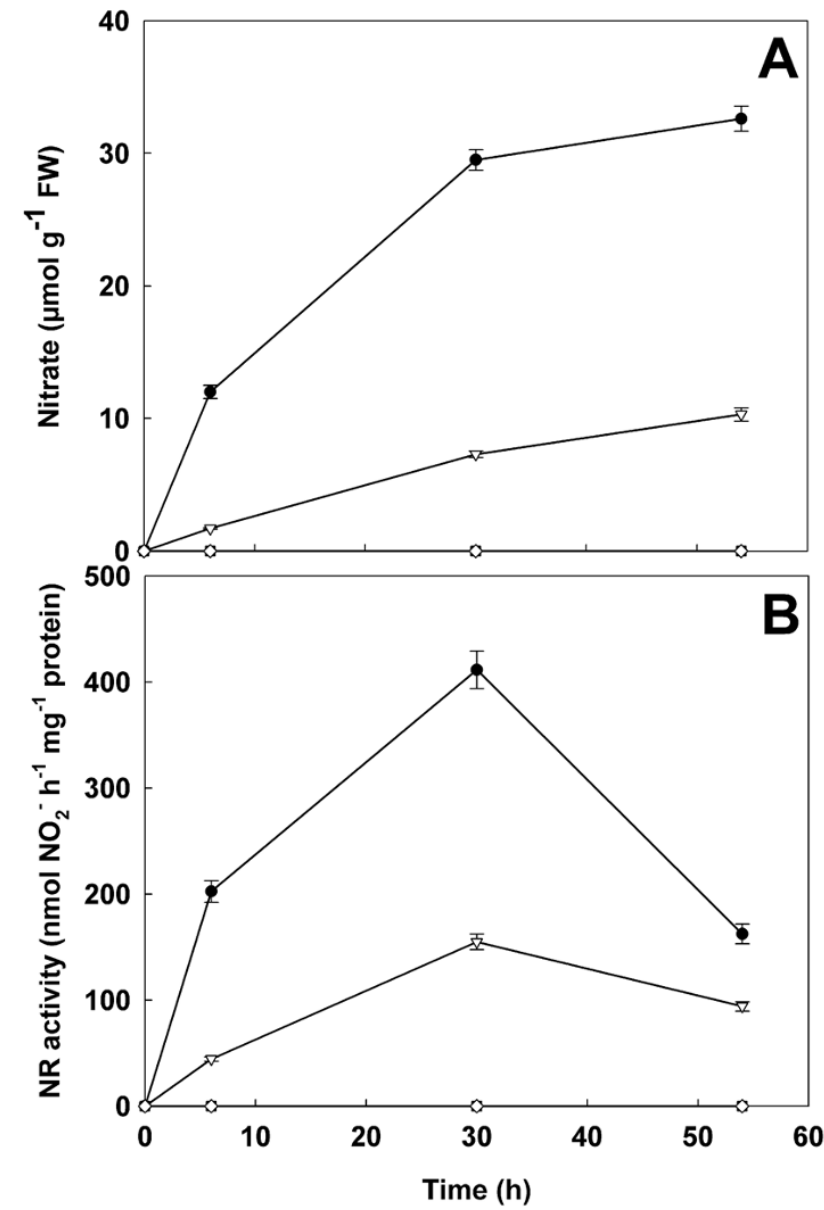

Figure 2

Nitrate content and nitrate reductase activity. Time course of the changes in nitrate content $(A)$ and nitrate reductase activity $(B)$ in roots (close circles and closed squares) and leaves (open triangle and open rhombuses) of Zea mays plants, previously grown for 17 days under nitrogen starvation $\left(T_{0}\right)$ and incubated for further 6,30 and $54 \mathrm{~h}$ in the absence (closed squares and open rhombuses) or in the presence (closed circles and open triangles) of $10 \mathrm{mM} \mathrm{NO}_{3}^{-}$. In roots and leaves of starved plants, both nitrate and NR activity were undetectable. Values are the mean \pm SE of three independent biological samples analyzed in triplicate ( $\mathrm{n}$ =9).

carbon skeleton is high, sucrose pool was also affected. The changes in carbohydrate availability and the increase of amino acid levels also explain the decrease in NR activity observed in roots at the $54^{\text {th }} \mathrm{h}$. In fact, these data are in agreement with the inhibitory effect on NR evocated by an increase of some amino acids, mainly asparagine and glutamine $[5,42]$. Moreover, it is know that NR activity increases after sucrose addition whilst the low sugar content, condition that we observed in the roots of $\mathrm{N}$ plants, affects the nitrate reduction system $[5,42,43]$. The results suggested that this feedback mechanism was activated in roots of the plants exposed for $54 \mathrm{~h}$ to $10 \mathrm{mM} \mathrm{NO}_{3}^{-}$. Finally, only at the $54^{\text {th }} \mathrm{h}$, a significant decrease in chlorophyll content (Figure 3I) was measured in the leaves of starved plants, thus suggesting that the first symptoms of stress were appearing.

\section{2-DE analysis and protein identification}

The biochemical and physiological data showed that the plants incubated for the last $30 \mathrm{~h}$ in the presence of 10 $\mathrm{mM} \mathrm{NO}_{3}{ }^{-}$were in a condition in which nitrogen metabolism is completely activated in both root and leaf organs and that, at the same time, no stress symptoms were detectable in the control plants. Starting from these results, the proteomic study was conducted by analyzing the soluble protein fractions extracted from roots and leaves of plants incubated for the last $30 \mathrm{~h}$ in the absence or in the presence of $10 \mathrm{mM} \mathrm{NO}_{3}^{-}$.

The ratio between dry and fresh weight as well as the total protein content appeared similar both in the roots and in the leaves of $\mathrm{C}$ and $\mathrm{N}$ samples (Table 1 ). The adopted protocol permitted to obtain an extraction yield of soluble proteins of about $14 \%$ and $20 \%$ for roots and leaves, respectively. Moreover, no significant differences were observed between $\mathrm{C}$ and $\mathrm{N}$ plants.

The 2-DE representative gels of the soluble fractions of root and leaf samples are shown in Figure 4. The electrophoretic analyses detected about 1100 and 1300 spots in roots and leaves gels, respectively. To ascertain the quantitative changes in the proteomic maps, the relative spot volumes $(\% \mathrm{Vol})$ were evaluated by software-assisted analysis. The Student's t-test $(p<0.05)$, coupled with a threshold of two-fold change in the amount, revealed that 20 spots in roots and 18 spots in leaves were affected by nitrogen availability.

The analysis of these spots by LC-ESI-MS/MS allowed to identify 15 and 14 proteins in root and leaf patterns, respectively. These proteins and the changes in their accumulation are shown in Tables 2 and 3, while further information of mass spectrometry (MS) analysis are reported in the Additional files 2 and 3.

\section{Functional role and quantitative change of the proteins identified in roots}

Many of the spots identified in roots were enzymes involved in nitrogen and carbon metabolisms (Table 2). According to the induction of the $\mathrm{NO}_{3}$ - assimilation pathway, in the roots of the plants incubated for the last $30 \mathrm{~h}$ in the presence of the nutrient, we observed an increase in the accumulation of nitrite reductase (spot 268, NiR) and of glutamine synthetase plastidial isoform (spot 483, GS2). 


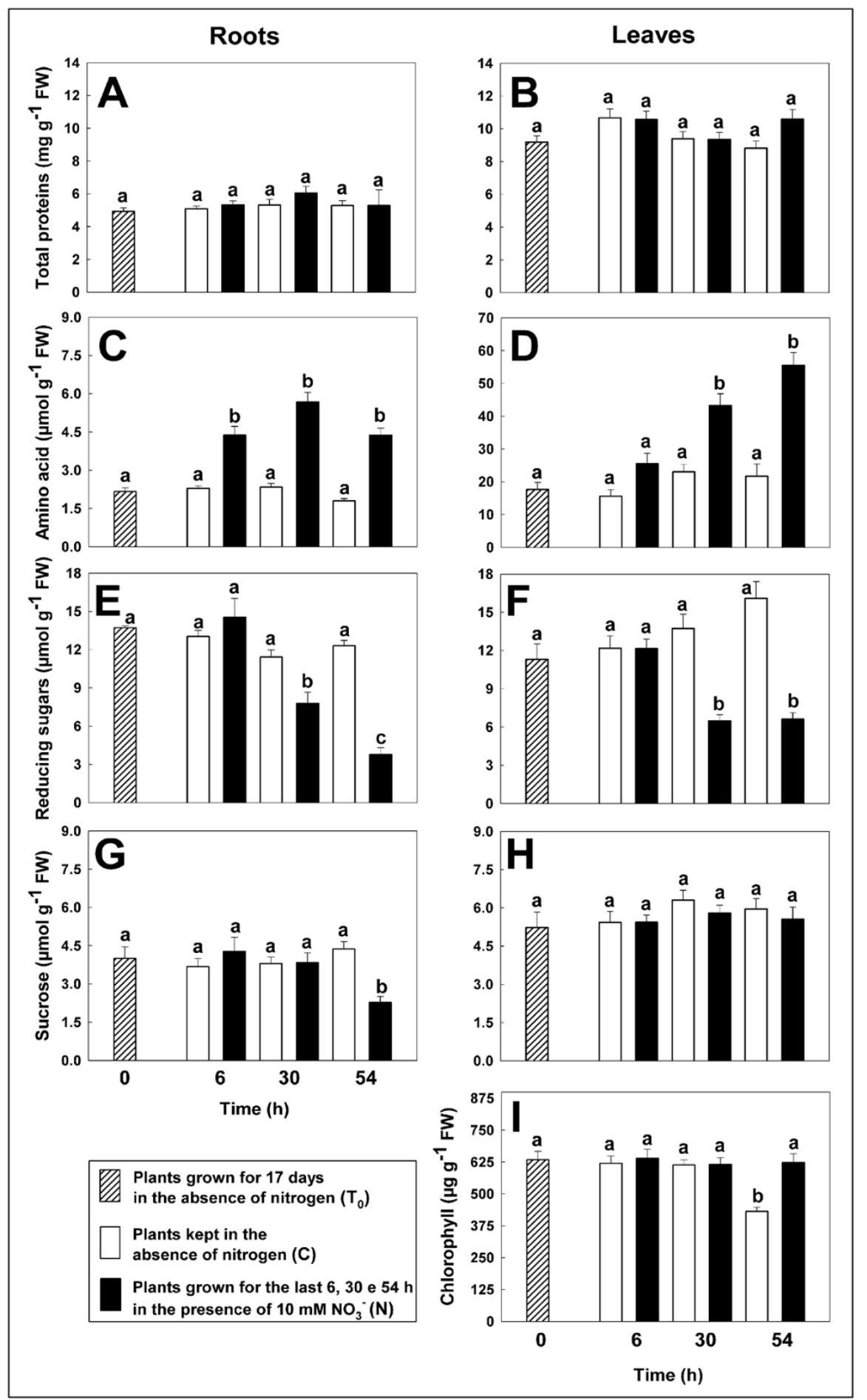

Figure 3

Total proteins, amino acids, reducing sugars, sucrose and chlorophyll content. Time course of the changes in the content of total proteins, amino acids, reducing sugars and sucrose in roots $(A, C, E$ and $G)$ and leaves $(B, D, F$, and $H)$ and chlorophyll content in leaves (I) of Zea mays plants, previously grown in the absence of nitrogen for 17 days ( $\left.T_{0}\right)$ and incubated for further 6,30 and $54 \mathrm{~h}$ in the absence $(\mathrm{C})$ or presence of $10 \mathrm{mM} \mathrm{NO}_{3}^{-}(\mathrm{N})$. Values are the mean $\pm \mathrm{SE}$ of three independent biological samples analyzed in triplicate $(n=9)$. Samples indicated with the same letters do not differ significantly according to Tukey's test $(p<0.01)$. 
Table I: Evaluation of the procedure for the extraction of soluble proteins from roots and leaves of plants grown in the two conditions compared in the proteomic analysis.

\begin{tabular}{ccccc}
\hline Organ & Condition & FW/DW & Total proteins $\left(\mathbf{m g ~ g}^{-1} \mathbf{F W}\right)$ & Extraction yield of soluble proteins (\%) \\
\hline \multirow{2}{*}{ Root } & C plants & $\mathbf{8 . 6 3} \pm 0.05$ & $\mathbf{5 . 3 2} \pm 0.34$ & $13.39 \pm 0.72$ \\
& N plants & $\mathbf{8 . 4 3} \pm 0.34$ & $\mathbf{6 . 0 4} \pm 0.41$ & $14.63 \pm 0.69$ \\
\multirow{2}{*}{ Leaf } & C plants & $\mathbf{8 . 4 5} \pm 0.09$ & $\mathbf{9 . 3 9} \pm 0.45$ & $19.17 \pm 0.99$ \\
& N plants & $\mathbf{8 . 6 4} \pm 0.15$ & $\mathbf{9 . 3 5} \pm 0.43$ & $\mathbf{2 0 . 9 6 \pm 0 . 4 3}$ \\
\hline
\end{tabular}

In the table, the fresh/dry weight (FW/DW), the content of total protein $\left(\mathrm{mg} \mathrm{g}^{-1} \mathrm{FW}\right)$ and the \% yield of the extraction of soluble proteins $(\%$ of extracted soluble proteins respect to the total content) for the roots and the leaves of the plants compared by proteomic analysis are reported. The fresh weight of the roots was $0.56 \pm 0.03$ and $0.60 \pm 0.04 \mathrm{~g}$ in $\mathrm{C}$ and $\mathrm{N}$ plants, respectively. The fresh weight of the leaves was $0.79 \pm 0.03$ and $0.86 \pm 0.04 \mathrm{~g}$ in $\mathrm{C}$ and $\mathrm{N}$ plants, respectively.

$\mathrm{C}$ plants: plants kept in the absence of nitrogen; $\mathrm{N}$ plants: plants grown for the last $30 \mathrm{~h}$ in the presence of $10 \mathrm{mM} \mathrm{NO}_{3}{ }^{-}$. Values are the mean $\pm \mathrm{SE}$ of three independent biological samples analyzed in triplicate $(n=9)$.

Moreover, in response to the demand of carbon skeletons and NADPH, which is used in non-green tissues for ferredoxin reduction [44], an increase in the levels of phosphoglycerate mutase (spot 216, PGAM-1), glucose-6phosphate dehydrogenase (spot 1162, G6PD) and 6phospho-gluconate dehydrogenase (spot 392, 6PGD) took place. These results well agree with previous array data that describe the responses to nitrate exposure in Arabidopsis and tomato $[7,29,45]$.

An increase in accumulation of the cytosolic isoform of glutamine synthetase (spot 538, GS1-1) was also detected in roots of $\mathrm{N}$ plants. On the basis of identified peptides by MS analysis it was possible to discriminate among the 5
GS1 isoforms known in Zea mays (SwissProt reviewed database) and to restrict the possible identification to 2 of them (GS1-1 [Swiss-Prot:P38559] and GS1-5 [SwissProt:P38563] [46]). The fact that Li and co-workers [46], through a Northern blot hybridization analysis, found that the transcript of GS1-1 gene was the only one expressed in roots, conducted to the specific identification of GS1-1 protein. Moreover, Sakakibara and co-workers [47] showed that GS1-1 transcript was the only induced by $\mathrm{NO}_{3}-$. The proteomic approach used in the present work allows to confirm these results at the translational level, demonstrating that in maize roots a cytosolic ammonia assimilation pathway can be activated also in response to nitrate.
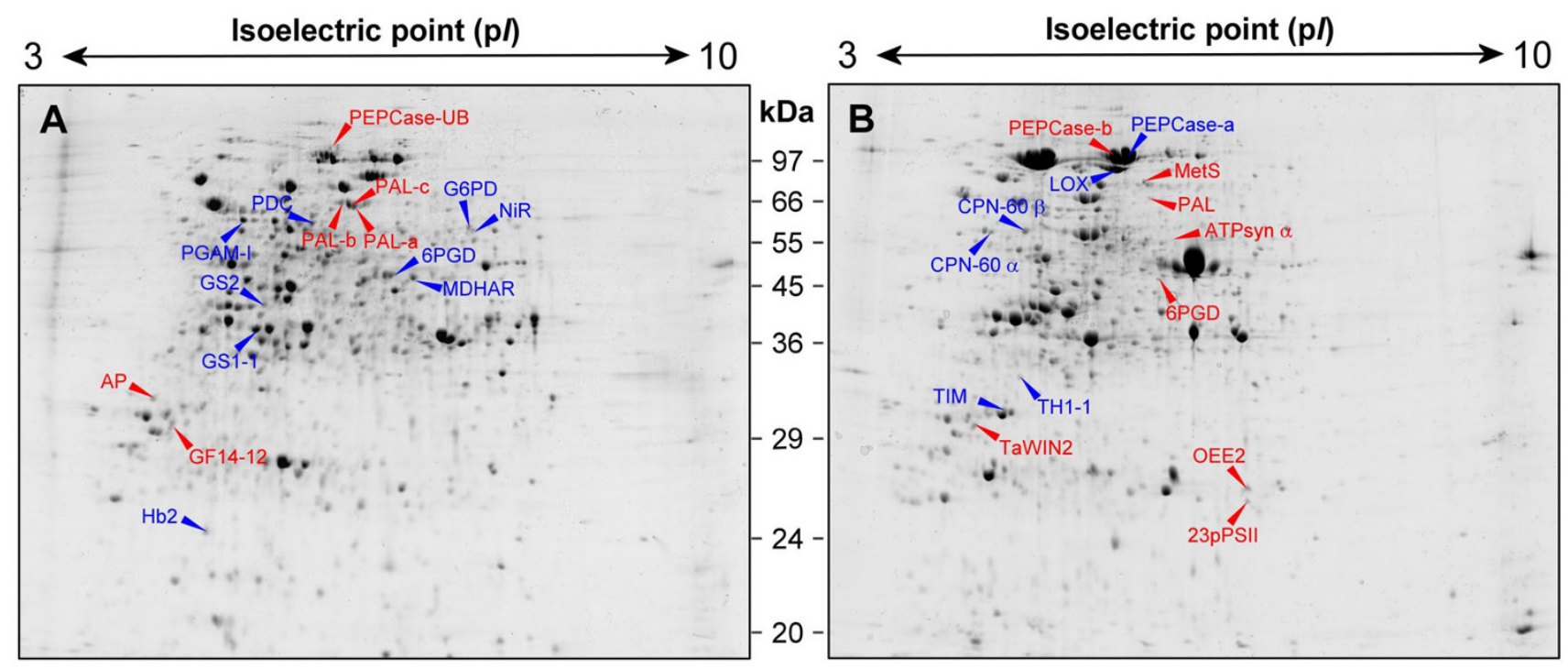

\section{Figure 4}

2-DE maps. Representative 2-DE maps of soluble protein fractions extracted from roots (A) and leaves (B) of Zea mays plants. Proteins $(400 \mu \mathrm{g})$ were analyzed by IEF at $\mathrm{pH} 3-10$, followed by $12.5 \%$ SDS-PAGE and visualized by CCBB-staining. Name abbreviations, corresponding to those in Tables 2 and 3, indicate the spots, identified by LC-ESI-MS/MS, showing significant changes of at least two-fold in their relative volumes ( $t$-test, $p<0.05$ ) after the exposure to $10 \mathrm{mM}$ nitrate for $30 \mathrm{~h}$. Proteins that increased or decreased after this treatment are reported in blue or in red, respectively. 
Table 2: List of the spots identified in the roots and their change in abundance after the exposure to $10 \mathrm{mM}$ nitrate for $30 \mathrm{~h}$.

\begin{tabular}{|c|c|c|c|c|c|c|c|}
\hline \multirow[t]{2}{*}{ Spot ID } & \multirow[t]{2}{*}{ Accession number } & \multirow[t]{2}{*}{ Protein description } & \multirow[t]{2}{*}{ Abbr. ${ }^{a}$} & \multirow[t]{2}{*}{$M_{r}^{b} / p / b$} & \multirow[t]{2}{*}{$M_{r} / p / c$} & \multicolumn{2}{|c|}{$\begin{array}{c}\text { Change in level } \\
\text { [Relative volume }(\%)]\end{array}$} \\
\hline & & & & & & Control & $10 \mathrm{mM} \mathrm{NO}_{3}$ \\
\hline \multicolumn{8}{|c|}{ Glycolysis, gluconeogenesis, C-compound and carbohydrate metabolism } \\
\hline \multirow[t]{2}{*}{53} & BAA28170 & Phosphoenolpyruvate carboxylase & PEPCase-UB & II5.4/5.7 & 109.4/5.7 & $0.223 \pm 0.022$ & $0.084 \pm 0.032$ \\
\hline & $\underline{\mathrm{P} 69319}$ & Ubiquitin & & & $8.5 / 6.6$ & & \\
\hline 216 & $\underline{\mathrm{P} 30792}$ & $\begin{array}{l}\text { 2,3-bisphosphoglycerate-independent } \\
\text { phosphoglycerate mutase }\end{array}$ & PGAM-I & $63.0 / 5.1$ & $60.6 / 5.3$ & $0.124 \pm 0.086$ & $0.245 \pm 0.011$ \\
\hline 231 & AAL99745 & Pyruvate decarboxylase & PDC & $62.4 / 5.5$ & $65.0 / 5.7$ & $0.080 \pm 0.043$ & $0.167 \pm 0.024$ \\
\hline 392 & $\overline{\text { EAZI8378 }}$ & 6-phosphogluconate dehydrogenase ${ }^{d}$ & 6PGD & $50.1 / 6.1$ & $50.1 / 5.5$ & $0.080 \pm 0.031$ & $0.275 \pm 0.033$ \\
\hline 1162 & NP 196815 & $\begin{array}{c}\text { Glucose-6-phosphate I- } \\
\text { dehydrogenase }\end{array}$ & G6PD & $60.3 / 6.7$ & $67.2 / 8.5$ & $0.002 \pm 0.001$ & $0.010 \pm 0.014$ \\
\hline \multicolumn{8}{|c|}{ Nitrogen metabolism, amino acid metabolism and protein/peptide degradation } \\
\hline 268 & ACG29734 & Ferredoxin-nitrite reductase & NiR & $59.7 / 6.7$ & $66.2 / 6.5$ & $0.035 \pm 0.054$ & $0.124 \pm 0.084$ \\
\hline 483 & $\underline{P 25462}$ & Glutamine synthetase, chloroplastic & GS2 & $42.2 / 5.2$ & $4 I .0 / 5.4 \mathrm{e}$ & $0.066 \pm 0.015$ & $0.137 \pm 0.059$ \\
\hline 538 & P38559 & Glutamine synthetase root isozyme I & GSI-I & $38.7 / 5.1$ & $39.2 / 5.6$ & $0.210 \pm 0.010$ & $0.480 \pm 0.039$ \\
\hline 707 & BAA06876 & Aspartic protease & AP & $31.6 / 4.6$ & $54.1 / 5.1$ & $0.051 \pm 0.043$ & $0.015 \pm 0.065$ \\
\hline \multicolumn{8}{|c|}{ Secondary metabolism } \\
\hline $17 \mid$ & AAL40137 & Phenylalanine ammonia-lyase & PAL-a & $68.6 / 5.9$ & $74.9 / 6.5$ & $0.476 \pm 0.034$ & $0.184 \pm 0.012$ \\
\hline 172 & AAL40I37 & Phenylalanine ammonia-lyase & PAL-b & $68.6 / 5.8$ & $74.9 / 6.5$ & $0.904 \pm 0.136$ & $0.277 \pm 0.026$ \\
\hline 1160 & AAL40I37 & Phenylalanine ammonia-lyase & PAL-c & $68.0 / 5.8$ & $74.9 / 6.5$ & $0.713 \pm 0.103$ & $0.275 \pm 0.034$ \\
\hline \multicolumn{8}{|c|}{ Cell rescue, defense and virulence } \\
\hline 390 & NP 001061002 & $\begin{array}{c}\text { Putative monodehydroascorbate } \\
\text { reductase }{ }^{d}\end{array}$ & MDHAR & $50.1 / 6.2$ & $52.8 / 6.8$ & $0.127 \pm 0.016$ & $0.275 \pm 0.033$ \\
\hline 960 & $\underline{\text { AAZ98790 }}$ & hemoglobin 2 & Hb2 & $24.8 / 4.9$ & $20.6 / 5.0$ & $0.018 \pm 0.061$ & $0.099 \pm 0.068$ \\
\hline \multicolumn{8}{|c|}{ Unknown } \\
\hline 774 & Q01526 & |4-3-3-like protein GFI4-|2 & GFI4-I 2 & $29.6 / 4.6$ & 29.6/4.7 & $0.345 \pm 0.034$ & $0.146 \pm 0.028$ \\
\hline
\end{tabular}

Statistical information about LC-ESI-MS/MS analysis are reported in Additional files 2 and 3 . Changes in the relative spot volumes are the mean \pm SE of six 2-DE gels derived from three independent biological samples analyzed in duplicate $(n=6)$. Proteins were classified according to MIPS funcat categories.

a: Protein abbreviation

$b$ : Experimental molecular weight $(\mathrm{kDa})$ or isoelectric point

c: Theoretical molecular weight $(\mathrm{kDa})$ or isoelectric point

$d$ : Information obtained by alignment of the sequence through BLAST analysis against NCBI $\mathrm{nr}$ database

e: Values referred to the mature form of the protein

Other spots that were found to increase their relative volumes in response to nitrate were a non-symbiotic hemoglobin and a monodehydroascorbate reductase (spot $960, \mathrm{Hb} 2$ and spot 390, MDHAR). In a previous work on Arabidopsis, it was found that $\mathrm{NO}_{3}$ - induced $A t H B 1$ and AtHB2, two genes that encode for non-symbiotic hemoglobins [7,29]. Scheible and co-workers [7] suggested that these proteins could change their abundance in relation to the redox status, whereas Wang and co-workers [29] speculated on the possibility that the induction of hemoglobin could aim at reducing oxygen concentration during NR synthesis, since molybdenium can be sensitive to oxygen. Besides, hemoglobin and MDHAR are known to be involved in the scavenging of NO that can be produced by cytosolic and/or plasmamembrane nitrate reductase when nitrite is used as substrate $[48,49]$. NO is a signaling molecule which is involved in many biochemical and physiological processes [50]. It has been reported that in plant roots, NO plays a role in growth, development and in some responses to environmental conditions, such as hypoxia [51]. Recently, a pos- sible involvement of $\mathrm{NO}$ in the mediation of nitratedependent root growth in maize has been suggested [52]. According to this work, that describes a reduction of endogenous $\mathrm{NO}$ at high external $\mathrm{NO}_{3}{ }^{-}$concentration, the observed concomitant up-accumulation of $\mathrm{Hb} 2$ and MDHAR in our experimental condition supports the hypothesis that they might contribute in controlling $\mathrm{NO}$ levels in root tissues after exposure to $\mathrm{NO}_{3}{ }^{-}[48,49,52]$.

The last protein found to be present in higher amount in $\mathrm{N}$ plants was a pyruvate decarboxylase (spot 231, PDC). This enzyme catalyzes the decarboxylation of pyruvic acid into acetaldehyde, the first step of the alcoholic fermentation. In particular, we identified the PDC isoenzyme 3 that has been previously found to be induced in hypoxia condition [53]. Although further studies are required to understand why PDC is induced by $\mathrm{NO}_{3}$, we can observe that fermentation pathways are induced in response to redox status changes and that this condition could be also linked to the activation of the $\mathrm{Hb} / \mathrm{NO}$ cycle (see above) $[49,54]$. 
Table 3: List of the spots identified in the leaves and their change in abundance after the exposure to $10 \mathrm{mM}$ nitrate for $30 \mathrm{~h}$.

\begin{tabular}{|c|c|c|c|c|c|c|c|}
\hline \multirow[t]{2}{*}{ Spot ID } & \multirow[t]{2}{*}{ Accession number } & \multirow[t]{2}{*}{ Protein description } & \multirow[t]{2}{*}{ Abbr. ${ }^{a}$} & \multirow[t]{2}{*}{$M_{r}^{b} / p / b$} & \multirow[t]{2}{*}{$M_{r} c / p / c$} & \multicolumn{2}{|c|}{$\begin{array}{c}\text { Change in level } \\
\text { [Relative volume (\%)] }\end{array}$} \\
\hline & & & & & & Control & $10 \mathrm{mM} \mathrm{NO}_{3}$ \\
\hline \multicolumn{8}{|c|}{ Nitrogen and amino acid metabolism } \\
\hline $1094^{\circ}$ & BABII740 & TaWIN2 & $\mathrm{TaWIN2}$ & 29.9/4.7 & $28.7 / 4.8$ & $0.182 \pm 0.009$ & $0.090 \pm 0.014$ \\
\hline 254 & AAL73979 & Methionine synthase protein & MetS & $83.4 / 5.9$ & $83.8 / 5.9$ & $0.148 \pm 0.020$ & $0.073 \pm 0.008$ \\
\hline \multicolumn{8}{|c|}{ C-compound and carbohydrate metabolism } \\
\hline 650 & $\mathrm{AAC} 27703$ & $\begin{array}{c}\text { Putative cytosolic 6-phosphogluconate } \\
\text { dehydrogenase }\end{array}$ & 6PGD & $47.4 / 6.0$ & $52.9 / 6.2$ & $0.088 \pm 0.005$ & $0.043 \pm 0.007$ \\
\hline \multicolumn{8}{|c|}{ Photosynthesis } \\
\hline 134 & $\underline{P 047 I I}$ & Phosphoenolpyruvate carboxylase I & PEPCase-a & 104.4/5.8 & 109.3/5.8 & $0.990 \pm 0.083$ & $2.770 \pm 0.295$ \\
\hline 138 & $\overline{\mathrm{P} 0471 \mathrm{I}}$ & Phosphoenolpyruvate carboxylase I & PEPCase-b & 104.4/5.7 & $109.3 / 5.8$ & $2.220 \pm 0.278$ & $1.090 \pm 0.205$ \\
\hline 500 & $\underline{\mathrm{P} 05022}$ & ATP synthase subunit alpha, chloroplastic & ATPsyn $\alpha$ & $55.9 / 6.1$ & $55.7 / 5.9$ & $0.042 \pm 0.007$ & $0.015 \pm 0.003$ \\
\hline 1065 & NP 001063777 & $\begin{array}{c}\text { Putative triosephosphate isomerase, } \\
\text { chloroplast precursor }{ }^{d}\end{array}$ & TIM & $31.0 / 4.9$ & $32.4 / 7.0$ & $0.028 \pm 0.009$ & $0.088 \pm 0.014$ \\
\hline 1244 & $\underline{000434}$ & $\begin{array}{c}\text { Oxygen-evolving enhancer protein } 2, \\
\text { chloroplast precursor }\end{array}$ & OEE2 & $26.6 / 6.5$ & $27.3 / 8.8$ & $0.201 \pm 0.013$ & $0.090 \pm 0.011$ \\
\hline 1612 & BAA08564 & $23 \mathrm{kDa}$ polypeptide of photosystem II & 23pPSII & $26.3 / 6.5$ & $27.0 / 9.5$ & $0.147 \pm 0.008$ & $0.055 \pm 0.006$ \\
\hline \multicolumn{8}{|c|}{ Protein folding and stabilization } \\
\hline 462 & NP 001056601 & $\begin{array}{c}\text { RuBisCO subunit binding-protein beta } \\
\text { subunit } d\end{array}$ & CPN-60 $\beta$ & $58.5 / 5.1$ & $64.1 / 5.6$ & $0.079 \pm 0.014$ & $0.164 \pm 0.015$ \\
\hline 467 & $\underline{\text { AAP44754 }}$ & $\begin{array}{l}\text { Putative rubisco subunit binding-protein } \\
\text { alpha subunit precursor }\end{array}$ & $\mathrm{CPN}-60 \alpha$ & $58.2 / 4.8$ & $61.4 / 5.4$ & $0.046 \pm 0.004$ & $0.096 \pm 0.004$ \\
\hline \multicolumn{8}{|c|}{ Metabolism of vitamins, cofactors, and prosthetic groups } \\
\hline 999 & $\underline{\mathrm{Q} 41738}$ & $\begin{array}{l}\text { Thiazole biosynthetic enzyme I-I, } \\
\text { chloroplast precursor }\end{array}$ & THI-I & $33.0 / 5.1$ & $32.8 / 4.9 e$ & $0.010 \pm 0.001$ & $0.048 \pm 0.003$ \\
\hline \multicolumn{8}{|c|}{ Secondary metabolism } \\
\hline 313 & AAL40I37 & Phenylalanine ammonia-lyase & PAL & $70.2 / 6.0$ & $74.9 / 6.5$ & $0.076 \pm 0.008$ & $0.023 \pm 0.002$ \\
\hline \multicolumn{8}{|c|}{ Lipid metabolism } \\
\hline 219 & $\mathrm{ABC} 59693$ & Lipoxygenase & LOX & $94.6 / 5.8$ & $102.1 / 6.1$ & $0.023 \pm 0.011$ & $0.149 \pm 0.011$ \\
\hline
\end{tabular}

Statistical information about LC-ESI-MS/MS analysis are reported in Additional files 2 and 3 . Changes in the relative spot volumes are the mean \pm SE of six 2-DE gels derived from three independent biological samples analyzed in duplicate $(n=6)$. Proteins were classified according to MIPS funcat categories.

a: Protein abbreviation

b: Experimental molecular weight $(\mathrm{kDa})$ or isoelectric point

c: Theoretical molecular weight $(\mathrm{kDa})$ or isoelectric point

$\mathrm{d}$ : Information obtained by alignment of the sequence through BLAST analysis against NCBI $\mathrm{nr}$ database

e: Values referred to the mature form of the protein

Among the spots identified in roots, six showed a downaccumulation in $\mathrm{N}$ plants (Table 2). Three of them were identified as phenylalanine ammonia-lyase (spots 171, 172 and 1160, PAL-a, PAL-b and PAL-c). The MS analysis indicated for all three spots the same protein [GenBank:AAL40137] while the electrophoretic data showed some differences in $\mathrm{M}_{\mathrm{r}}$ and $\mathrm{p} I$, suggesting that post-translational modification events may have occurred. It has been shown as low nitrogen availability induces transcripts encoding enzymes of phenylpropanoid and flavonoid metabolism, such as PAL, chalcone synthase and 4coumarate:coenzyme A ligase, whilst after nitrogen repletion these activities are down-regulated $[7,55]$. Our proteomic data appear to be in agreement with these studies.

Previously, it was found that under low nitrogen availability four proteases (e.g. serine, aspartate/metalloproteases and two cysteine proteases) increased their activity to degrade non-essential proteins in order to remobilize this nutrient [56]. In this work, we found an aspartic protease belonging to the A1 family (spot 707, AP) that was downregulated after $\mathrm{NO}_{3}-$ exposure. Moreover, the experimental $\mathrm{M}_{\mathrm{r}}$ appeared lower with respect to that expected for this protein, thus suggesting that this spot is referable to the active form of the enzyme [57]. These data support a new possible role for A1 protease family $[57,58]$.

Phosphoenolpyruvate carboxylase activity is known to increase during nitrate assimilation, having a role in cell $\mathrm{pH}$ homeostasis and an anaplerotic function [14,19,5961]. In addition, the monoubiquitination of this enzyme was recently well described in germinating castor oil seeds by Uhrig and co-workers [62]. It was found that this event is non-destructive and that this reversible post-translational modification of the enzyme reduces its affinity for PEP and its sensitivity to allosteric activators and inhibi- 
tors. The MS analysis of spot 53 (for sequence details see Additional file 4) identified 8 peptides, 7 of which matched with a PEPCase [DDBJ:BAA28170] (theoretical $\mathrm{M}_{\mathrm{r}} / \mathrm{pI}$ equal to 109.4/5.7), while the last peptide belonged to an ubiquitin (UB) [Swiss-Prot:P69319] (theoretical $\mathrm{M}_{\mathrm{r}}$ / $\mathrm{p} I$ equal to 8.5/6.6). The experimental $\mathrm{M}_{\mathrm{r}}$ and $\mathrm{p} I$ of spot 53, that were 115.4 and 5.7 respectively, were in agreement with the monoubiquitination of the PEPCase (PEPCase-UB, theoretical $\mathrm{M}_{\mathrm{r}} / \mathrm{pI}$ equal to $117.9 / 5.8$ respectively). Moreover, the domain responsible to bind ubiquitin previously identified in PEPCase of other vascular plants is present in this maize PEPCase [62]. These results suggest that in maize roots the modulation of PEPCase activity in response to nitrogen availability could occur also through reversible monoubiquitination.

The last spot identified in roots that was down-regulated by $\mathrm{NO}_{3}{ }^{-}$was the 14-3-3-like protein GF14-12 (spot 774, GF14-12). Previously, it was found that this protein is localized in the nucleus where it binds the DNA at the Gbox regions in association with transcription factors and that it is involved in the regulation of gene expression $[63,64]$. More recently, it was described an interaction of 14-3-3 proteins with some transcription factors such as VP1, EmBP1, TBP and TFIIB [65]. Further studies are required to clarify the effective role of GF14-12, for which the functional information are still lacking.

\section{Functional role and quantitative change of the proteins identified in leaves}

Many of the spots identified in leaves by LC-ESI-MS/MS analysis were proteins linked to the $\mathrm{NO}_{3}$ - assimilation as well as to the photosynthetic activity (Table 3 ).

The activity of NR can be modulated also at post-translational level through a phosphorylation event followed by binding of inhibitory $14-3-3$ protein $[66,67]$. One of the spots analyzed in the leaves was identified as TaWIN2 (Table 3, spot 1094, TaWIN2), that was previously described to be involved in the NR inactivation [67]. We found that the level of this protein decreased in leaves of $\mathrm{N}$ plants, where NR activity was induced (Table 3 ).

According to the well known relationships existing between nitrogen and carbon metabolism, the changes in accumulation of some spots after $\mathrm{NO}_{3}$ - addition are consistent with an increase of photosynthesis rate. Two spots that raise after $\mathrm{NO}_{3}$ - addition were identified as CPN-60 $\alpha$ and CPN-60 (spot 467 and 462, CPN-60 $\alpha$ and CPN-60 $\beta$, respectively), that are chaperonin proteins involved in folding of ribulose-1,5-bisphosphate carboxylase [68]. Moreover, a chloroplastic triosephosphate isomerase was up-regulated by $\mathrm{NO}_{3}{ }^{-}$(spot 1065, TIM), while a cytosolic 6-phosphogluconate dehydrogenase (spot 650, 6PGD) was down-regulated, as expected when the request of reducing power could be satisfied by the increase in photosynthetic activity [69].

Spot 500 was identified as the $\alpha$ subunit of the chloroplastic ATP synthase (ATPsyn $\alpha$ ), but unexpectedly it was more abundant in leaves of $C$ plants. Although only a speculative interpretation of this result can be made, we could hypothesize that in leaves of the N plants ATP synthase should be activated and this process requires the reconstitution of the enzymatic complex in the thylakoid membranes [70]. Hence, to clarify this point, it should be necessary to investigate if the decrease of ATPsyn $\alpha$ observed in the soluble fraction of $\mathrm{N}$ plants is effectively accompanied by an increase of this protein in the membrane fraction.

Thiamine (i.e. vitamin $\mathrm{B}_{1}$ ) is required in many pathways, such as the Calvin cycle, the branched-chain amino acid pathway and pigment biosynthesis [71]. Along with higher request of this vitamin in leaves of $\mathrm{N}$ plants, where the activation of these pathways could take place, we identified, among the spots up-regulated by $\mathrm{N}$, the thiazole biosynthetic enzyme (spot 999, TH1-1) that is known to be involved in thiamine biosynthesis [71].

Two spots were identified as PEPCase (spot 134 and 138, PEPCase-a and PEPCase-b respectively). In $\mathrm{C}_{4}$ plants such as maize, this enzyme plays a central role in photosynthesis, because it catalyses the primary fixation of atmospheric $\mathrm{CO}_{2}$ [72]. The catalytic activity and sensitivity of this enzyme are mediated by a reversible phosphorylation [73]. The experimental pIs of the spots 134 and 138 were 5.8 and 5.7, respectively. Moreover, these two PEPCase forms showed opposite changes in abundance in the leaves of plants grown in the last $30 \mathrm{~h}$ in the presence of $\mathrm{NO}_{3}{ }^{-}$with respect to the controls. The results obtained in our work suggest that the two spots of PEPCase are referable to the phosphorylated (spot 138) and to the unphosphorylated (spot 134) form with a predicted $\mathrm{pI}$ of 5.7 and 5.8 , respectively, that are known to correspond to the more and less active states of this enzyme [74]. Interestingly, despite the fact that data suggest an increase in the photosynthetic activity, the phosphorylated form was more abundant in the proteomic map of $\mathrm{C}$ plants. These results support the immunological observation by Ueno and co-workers [73] that the diurnal regulation of phosphorylation state of PEPCase appears delayed in nitrogenlimited conditions, suggesting that the circadian control of PEPcase is affected by nitrogen starvation.

Two of the spots down-regulated in leaves of $\mathrm{N}$ plants were a phenylalanine ammonia-lyase (spot $313, \mathrm{PAL}$ ) and a methionine synthase (spot 254, MetS). The decrease of PAL, observed also in root tissue (see above), is a further evidence that phenylpropanoid and flavonoid metabo- 
lisms are affected by nitrogen availability $[7,55]$. On the other hand, the change in accumulation of MetS is contrasting with a recent proteomic study performed on wheat by Bahrman and co-workers [39]. These authors found that the induction of this enzyme was positively related to nitrogen availability. This discrepancy could be associated to different genetic traits of the two species, as well as it could be linked to different experimental approaches adopted in the two studies. Nevertheless, it should be observed that in both these works a single spot referable to MetS was detected, while further information on total level and/or on activity of this enzyme is necessary to clarify this point.

The spot 219, which considerably increased in N plants, was a lipoxygenase (LOX). In particular, the analysis of the MS spectra identified the LOX codified by ZmLOX10 gene, which was found to be a plastidic type 2 linoleate 13LOX [75]. The expression analysis of this gene revealed that its transcript was abundant in leaves and was regulated by a circadian rhythm with a trend strictly linked to the photosynthetic activity. Moreover, it has been proposed that ZmLOX10 is involved in the hydroperoxide lyase-mediated production of $\mathrm{C}_{6}$-aldehydes and alcohols and not in the biosynthesis of JA [75]. Although some evidences suggest a role of ZmLOX10 in the responses to (a)biotic stresses, its involvement in the diurnal lipid metabolism was also proposed $[75,76]$.

At the same time, we identified two proteins as an oxygenevolving enhancer protein 2 (spot 1244, OEE2) and a 23 kDa polypeptide of photosystem II (spot 1612, 23pPSII), which were down-accumulated in leaves of $\mathrm{N}$ plants (Table 3). Both have been classified as members of PsbP family that is one of the three extrinsic protein families composing the oxygen-evolving complex (OEC) of photosystem II in higher plants [77-79]. In addition, it was recently demonstrated that PsbP proteins are essential for the normal function of PSII and play a crucial role in stabilizing the Mn cluster in vivo [80]. Moreover, the stability of this class of protein seems related to the lipid composition of chloroplastic membranes that is also affected by nitrogen availability $[81,82]$.

In order to elucidate the physiological meaning of these variations and to verify if they could be related to a stress status or to an alteration in photosynthetic performance, changes of both maximum quantum yield of photosystem II ( $F_{\mathrm{V}} / F_{\mathrm{M}}$; dark adapted plants) and effective quantum yield of photosystem II ( $\Phi_{\text {II }}$; light adapted plants), dry weight and MDA levels of shoot were measured (Figure 5 ). Although the $F_{\mathrm{V}} / F_{\mathrm{M}}$ parameter, measured on overnight dark adapted plants at time points 0,24 and 48 hours, resulted in very similar values between $\mathrm{C}$ and $\mathrm{N}$ plants (about 0.80; see also Figure 5A), the $\Phi_{\text {II }}$ values showed a very slight decrease in $\mathrm{C}$ plants during the second period of illumination (C plants $\Phi_{\mathrm{II}}, 0.71$ versus $\mathrm{N}$ plants, 0.73) and the difference became more marked between 48 and 54 hours of nitrogen starvation. Similar data could be obtained by monitoring biomass production at the different time points (Figure 5B), indicating that photosynthetic performances are highly impaired in C plants after 48-54 hours of treatment. Nevertheless, no changes in MDA were detected in all the conditions tested (Figure 5C).

Taken together these results indicate that at the $30^{\text {th }} \mathrm{h}$, the time point chosen for proteomic analysis, plants start feeling the different nitrogen content in the growth media without developing major stress symptoms and the associated pleiotropic effects.

These data sustain the hypothesis that ZmLOX10 could be involved in lipid metabolism of the chloroplast that is strictly depending on photosynthetic activity $[75,76]$. Further analyses are needed to unravel this possible intriguing role of ZmLOX10.

Considering the PsbP proteins, the change in accumulation of OEE2 and 23pPSII could indicate that OEC stability is affected by the $\mathrm{N}$ availability. Through time-course experiments, it will be possible to better correlate the relationship among $\mathrm{N}$ nutritional status, lipid metabolism, PsbP protein levels and PSII functionality.

\section{Conclusion}

Many of the proteins found to change in accumulation in response to $\mathrm{NO}_{3}{ }^{-}$were directly involved in the assimilation of this mineral nutrient. Moreover, the results underline the strict relationship between nitrogen and carbon metabolisms. The experimental design chosen for this proteomic study allows to emphasize some intriguing metabolic activities in both organs. Besides a dramatic increase of $\mathrm{NO}_{3}{ }^{-}$assimilation pathway, the exposure to a high $\mathrm{NO}_{3}$ - concentration after a starvation period seems to induce a modification in NO metabolism in roots, that could depend on the need of responding to the new nutritional status. In leaves, many proteins were found to be (in)directly involved in the photosynthesis reactivation and in the maintenance of the chloroplastic functionality.

In addition, this proteomic analysis confirms the modulation by phosphorylation of the PEPCase in the leaves, suggesting that nitrogen availability could affect the circadian rhythms, as well as it shows that the form of this enzyme operating in roots could be modulated by monoubiquitination. Although further efforts are required to elucidate these results, the present study underlines the central role of post-translational events to modulate pivotal enzymes in plant metabolic response to $\mathrm{NO}_{3}$. 


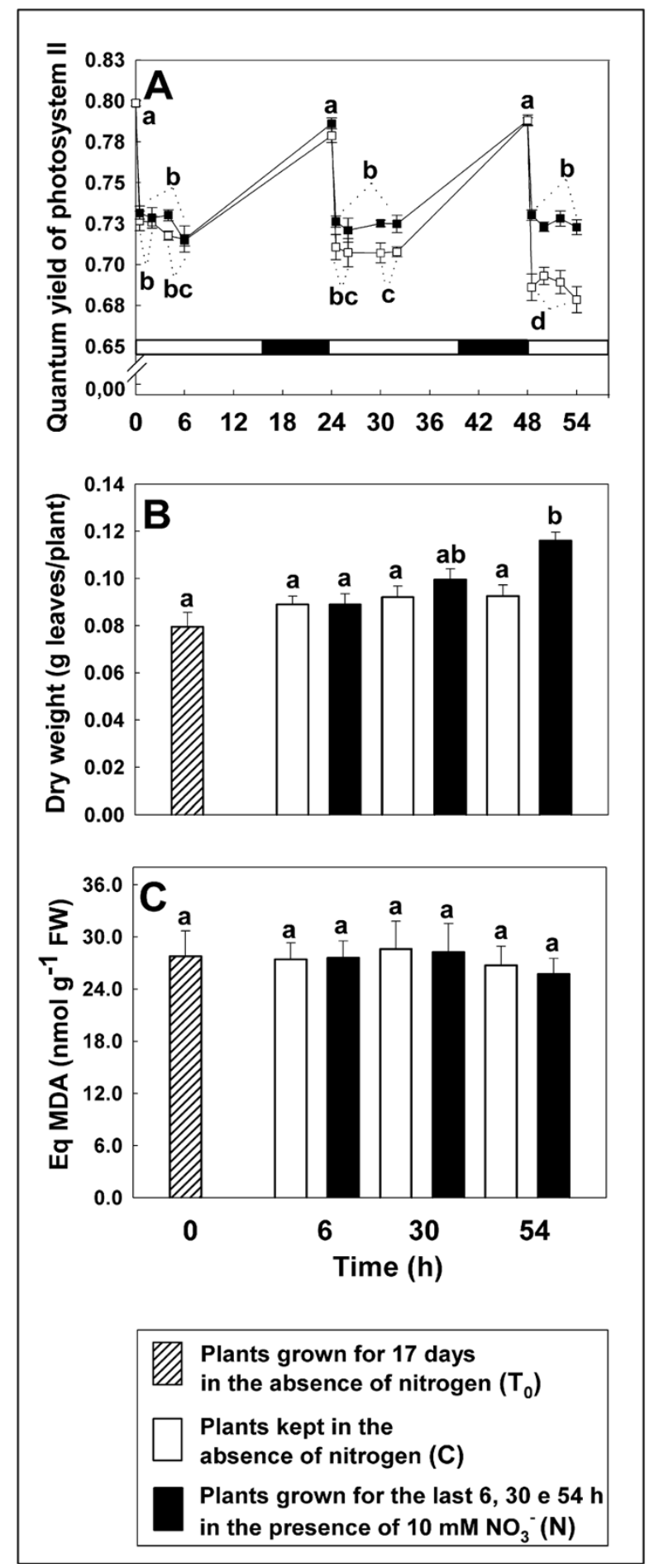

Figure 5

$\boldsymbol{F}_{\mathrm{V}} / \boldsymbol{F}_{\mathbf{M}}, \Phi_{\| \mid}$, dry weight and MDA in leaves. Time course of the changes in $F_{V} / F_{M}$ and $\Phi_{\| I}(A)$, dry weight in leaves (B) and MDA levels $(C)$ of Zea mays plants, previously grown for 17 days under nitrogen starvation $\left(T_{0}\right)$ and incubated for further 6 , 30 and $54 \mathrm{~h}$ in the absence or presence of $10 \mathrm{mM} \mathrm{NO}_{3}^{-}$. Symbol in Figure A: open squares, Control; closed squares, $10 \mathrm{mM} \mathrm{NO}_{3}-$ ; horizontal bar: white bars, light periods; black bars, dark periods (for details see Figure I). Values are the mean \pm SE of three independent biological samples analyzed in triplicate $(n=9)$. Samples indicated with the same letters do not differ significantly according to Tukey's test $(p<0.0 \mathrm{I})$. 


\section{Methods}

Plant material and growth conditions

Maize (Zea mays L.) seeds of T250 inbred line, kindly provided by Prof. Zeno Varanini of Udine University - Italy, were germinated in the dark at $26^{\circ} \mathrm{C}$ on blotting paper saturated with deionized water. After $72 \mathrm{~h}$, seedlings were transferred to a hydroponic system placed in a growth chamber with a day/night regime of $16 / 8 \mathrm{~h}$ and a PPFD of $200 \mu \mathrm{mol} \mathrm{m} \mathrm{m}^{-2} \mathrm{~s}^{-1}$ at plant level, with a temperature of $22^{\circ} \mathrm{C}$ in the dark and $26^{\circ} \mathrm{C}$ in the light and with a relative humidity of $70 \%$. Seedlings were grown using of the following solutions: (i) $4 \mathrm{mM} \mathrm{CaSO}_{4}$ for the first $48 \mathrm{~h}$; (ii) $0.4 \mathrm{mM} \mathrm{CaSO}_{4}, 0.2 \mathrm{mM} \mathrm{K}_{2} \mathrm{SO}_{4}, 0.175 \mathrm{mM} \mathrm{KH}_{2} \mathrm{PO}_{4}, 0.1$ $\mathrm{mM} \mathrm{MgSO}_{4}, 5 \mu \mathrm{M} \mathrm{KCl}, 20 \mu \mathrm{M}$ Fe-EDTA, $2.5 \mu \mathrm{M} \mathrm{H}_{3} \mathrm{BO}_{3}$, $0.2 \mu \mathrm{M} \mathrm{MnSO}_{4}, 0.05 \mu \mathrm{M} \mathrm{CuSO}_{4}, 0.2 \mu \mathrm{M} \mathrm{ZnSO}_{4}, 0.05 \mu \mathrm{M}$ $\mathrm{Na}_{2} \mathrm{MoO}_{4}$ (growing solution) for the following 12 days. After this 17 days-long period of $\mathrm{N}$ starvation $\left(\mathrm{T}_{0}\right)$, plants were transferred in a fresh growing solution added $(\mathrm{N})$ or not (C) with $10 \mathrm{mM} \mathrm{KNO}_{3}$. The $\mathrm{pH}$ of all the growth solutions was adjusted to 6.1 and the solutions were changed every three days. All hydroponic solutions were continuously aerated by an electric pump.

At $\mathrm{T}_{0}$ stage and after a period of 6, 30 and $54 \mathrm{~h}$ plants were harvested, washed with distilled water and then blotted with paper towels. Finally, roots and leaves were separated and the samples were frozen in liquid $\mathrm{N}_{2}$ and stored at $80^{\circ} \mathrm{C}$. The roots used for determining nitrate content were rinsed twice in ice-cold $0.4 \mathrm{mM} \mathrm{CaSO}_{4}$ solution for 15 min for removing the anion present in the apoplast before sampling.

\section{Levels of nitrate}

Nitrate was extracted from the tissues by homogenizing the samples previously boiled in 4 volumes of distilled water for $15 \mathrm{~min}$. The homogenate was centrifuged at $12,000 \mathrm{~g}$ for $20 \mathrm{~min}$ to obtain a clarified supernatant. Nitrate content was measured by adding $0.8 \mathrm{ml}$ of $5 \%$ (w/ v) salicylic acid in concentrated sulfuric acid solution to $0.2 \mathrm{ml}$ of the supernatant. The mixture was stirred vigorously and allowed to react over $20 \mathrm{~min}$, afterwards $19 \mathrm{ml}$ of $2 \mathrm{~N} \mathrm{NaOH}$ were slowly added and the resulting colour was read at $410 \mathrm{~nm}$ [83].

\section{Nitrate reductase activity}

NR was extracted by using 4 volumes of ice-cold $50 \mathrm{mM}$ pH 7.8 MOPS-KOH buffer containing 5 mM EDTA, $5 \mathrm{mM}$ NaF, 2 mM MSH, 1 mM PMSF, $10 \mu \mathrm{M}$ FAD, $1 \mu \mathrm{M}$ leupeptin and $10 \mu \mathrm{M}$ chymostatin. The homogenates were centrifuged at $13,000 \mathrm{~g}$ for $15 \mathrm{~min}$ at $4^{\circ} \mathrm{C}$. NR activity was measured as described by Ferrario-Méry et al. [84] using a reaction mixture consisting of $50 \mathrm{mM}$ pH 7.5 MOPS-KOH buffer, $1 \mathrm{mM} \mathrm{NaF}, 10 \mathrm{mM} \mathrm{KNO}{ }_{3}, 0.17 \mathrm{mM}$ NADH, 10 $\mathrm{mM} \mathrm{MgCl}_{2}$ and $5 \mathrm{mM}$ EDTA. The reaction was blocked after 10 or $20 \mathrm{~min}$ by adding an equal volume of sulphanilamide $(1 \%, \mathrm{w} / \mathrm{v}$ in $3 \mathrm{M} \mathrm{HCl})$ followed by n-naphtylethylethylenediamine dihydrochloride $(0.02 \%, \mathrm{w} / \mathrm{v}) .30 \mathrm{~min}$ later, the concentration of $\mathrm{NO}_{2}^{-}$was determined spectrophotometrically at $540 \mathrm{~nm}$. The protein concentration was determined by 2-D Quant Kit (GE Healthcare).

\section{Determination of reducing sugars, sucrose, amino acids, total proteins and chlorophyll}

Reducing sugars, sucrose and amino acids were extracted by homogenizing frozen tissues in 4 volumes of ice-cold $0.5 \mathrm{M}$ perchloric acid (PCA). The homogenate was centrifuged for $10 \mathrm{~min}$ at $13,000 \mathrm{~g}$ at $4^{\circ} \mathrm{C}$ and the resulting pellet was washed with the same volume of PCA and then centrifuged again in the same conditions. $\mathrm{KOH}$ was added to the collected supernatant (to $\mathrm{pH} 7.6$ ) to remove excess PCA. Reducing sugars were measured according to the colorimetric method by Nelson [85]. Total soluble sugars were determined by the same method boiling an aliquot of PCA extract for $1 \mathrm{~h}$ before neutralization. Sucrose was estimated from the difference between total soluble and reducing sugars. Total amino acids were measured by the ninhydrin method [86].

Total proteins were extracted as previously described by Martínez and co-workers [87] by homogenizing the samples, previously powdered in liquid nitrogen, in 4 volumes of a $125 \mathrm{mM}$ pH 8.8 Tris-HCl buffer containing 1\% $(\mathrm{w} / \mathrm{v})$ SDS, $10 \%(\mathrm{w} / \mathrm{v})$ glycerol, $50 \mathrm{mM} \mathrm{Na}_{2} \mathrm{~S}_{2} \mathrm{O}_{5}$. The homogenate was centrifuged at $13,000 \mathrm{~g}$ for $20 \mathrm{~min}$ to obtain a clarified supernatant. The protein content was measured by using 2-D Quant Kit (GE Healthcare).

Chlorophyll was extracted by homogenizing the leaves, previously powdered in liquid nitrogen, in 4 volumes of $80 \%$ pre-cooled acetone $(\mathrm{v} / \mathrm{v})$. The homogenate was centrifuged at $13,000 \mathrm{~g}$ for $20 \mathrm{~min}$ at $4^{\circ} \mathrm{C}$ to obtain a clarified supernatant. Chlorophyll concentration was measured according to Lichtenthaler [88].

\section{Determination of malondialdehyde and chlorophyll fluorescence of the leaves}

Malondialdehyde (MDA) was assayed by the method of Heath \& Packer [89]. Frozen samples were homogenized with 4 volumes of ice-cold $0.1 \%(\mathrm{w} / \mathrm{v})$ trichloroacetic acid (TCA) and centrifuged at $13,000 \mathrm{~g}$ for $20 \mathrm{~min}$ at $4^{\circ} \mathrm{C}$. An equal volume of $20 \%(\mathrm{w} / \mathrm{v})$ TCA plus $0.5 \%(\mathrm{w} / \mathrm{v})$ thiobarbituric acid was added to the supernatants, which were subsequently heated at $95^{\circ} \mathrm{C}$ for $30 \mathrm{~min}$. The extracts were then clarified by centrifugation at $13,000 \mathrm{~g}$ for $10 \mathrm{~min}$, and the difference between the absorbance at 532 and 600 $\mathrm{nm}$ was measured. The MDA equivalent was calculated from the resulting difference using the extinction coefficient of $155 \mathrm{mM}^{-1} \mathrm{~cm}^{-1}$. 
In order to determine the photosynthetic performance, the chlorophyll fluorescence was measured by using a portable continuous-excitation type fluorometer (HandyPEA, Hansatech Instrument). The maximum quantum efficiency of photosystem II $\left(F_{\mathrm{V}} / F_{\mathrm{M}}\right)$ was calculated on over-night dark adapted plants, according to the equation $\left(F_{\mathrm{M}}-F_{0}\right) / F_{\mathrm{M}}$, where $F_{0}$ and $F_{\mathrm{M}}$ are the fluorescence levels when plastoquinone electron acceptor pool $(\mathrm{Qa})$ is fully oxidized and transiently fully reduced, respectively [90]. The photosynthetic performance of light adapted plants was evaluated by monitoring the effective quantum yield of photosystem II $\left(\Phi_{\text {II }}\right)$ defined as $\left(F_{\mathrm{M}^{\prime}}-F_{0}{ }^{\prime}\right) / F_{\mathrm{M}}{ }^{\prime}[91]$, where $F_{\mathrm{M}}$ 'and $F_{0}{ }^{\prime}$ represent the maximal and minimal fluorescence emission of photosystem II under light conditions.

\section{Statistical analyses of biochemical and physiological measurements}

For all the biochemical and physiological measurements, the experimental design consisted in three independent biological samples each analyzed in triplicate $(n=9)$.

One-way analysis of variance (ANOVA) followed by the post hoc Tukey test $(p<0.01)$ was used to verify the significance of the variations measured among all the tested parameters. This statistical analysis was performed using the software STATISTICA 7.

\section{Extraction of protein samples for 2-DE analysis}

Three independent biological replicates were extracted for each condition. Frozen samples, each composed by leaves or roots of 6 plants, were finely powdered in liquid nitrogen using a pestle and mortar, added with PVPP [0.5\% and $1 \%(\mathrm{w} / \mathrm{w})$ for roots and leaves samples, respectively], homogenized in 4 volumes of extraction buffer $[0.5 \mathrm{M}$ Tris-HCl pH 8, $0.7 \mathrm{M}$ sucrose, $10 \mathrm{mM}$ EDTA, $1 \mathrm{mM}$ PMSF, $1 \mu \mathrm{M}$ leupeptin, $0.1 \mathrm{mg} \mathrm{mL}^{-1}$ Pefabloc (Fluka), $0.2 \%$ (v/v) MSH] and centrifuged at $13,000 \mathrm{~g}$ at $4^{\circ} \mathrm{C}$ for $20 \mathrm{~min}$. The resultant supernatant was centrifuged at $100,000 \mathrm{~g}$ at $4{ }^{\circ} \mathrm{C}$ for $38 \mathrm{~min}$ to obtain the soluble fraction. Proteins were then purified using the method previously described by Hurkman and Tanaka [92] by adding an equal volume of ice-cold Tris buffered phenol (pH 8) to the supernatant. Samples were shaken for $30 \mathrm{~min}$ at $4{ }^{\circ} \mathrm{C}$, incubated for $2 \mathrm{~h}$ at $4{ }^{\circ} \mathrm{C}$ and finally centrifuged at $5,000 \mathrm{~g}$ for $20 \mathrm{~min}$ at $4{ }^{\circ} \mathrm{C}$ to separate the phases. Proteins, grouped in the upper phenol phase, were precipitated by the addition of five volumes of $-20^{\circ} \mathrm{C}$ pre-cooled $0.1 \mathrm{M}$ ammonium acetate in methanol and the incubation at $-20^{\circ} \mathrm{C}$ overnight. Precipitated proteins were recovered by centrifuging at $13,000 \mathrm{~g}$ at $4{ }^{\circ} \mathrm{C}$ for $30 \mathrm{~min}$ and then washed again with cold methanolic ammonium acetate and three times with cold $80 \%$ $(\mathrm{v} / \mathrm{v})$ acetone. The final pellet was dried under vacuum and dissolved in IEF buffer [7 $\mathrm{M}$ urea, $2 \mathrm{M}$ thiourea, 3\% $(\mathrm{w} / \mathrm{v})$ CHAPS, $1 \%(\mathrm{v} / \mathrm{v})$ octylphenoxy polyethoxy ethanol
(NP-40), $50 \mathrm{mg} \mathrm{mL}^{-1}$ DTT and 2\% (v/v) IPG Buffer pH 310 (GE Healthcare)] by vortexing and incubating for $1 \mathrm{~h}$ at room temperature. Samples were centrifuged at 10,000 $g$ for $10 \mathrm{~min}$ and the supernatants stored at $-80^{\circ} \mathrm{C}$ until further use. Protein concentration was determined by 2-D Quant Kit (GE Healthcare).

\section{2-DE analysis}

Protein samples $(400 \mu \mathrm{g})$ were loaded on $\mathrm{pH} 3-10,24 \mathrm{~cm}$ IPG strips passively rehydrated overnight in $7 \mathrm{M}$ urea, $2 \mathrm{M}$ thiourea, 3\% (w/v) CHAPS, $1 \%(\mathrm{v} / \mathrm{v}) \mathrm{NP}-40,10 \mathrm{mg} \mathrm{mL}^{-1}$ DTT and $0.5 \%(\mathrm{v} / \mathrm{v})$ IPG Buffer $\mathrm{pH} 3-10$. IEF was performed at $20^{\circ} \mathrm{C}$ with current limit of $50 \mu \mathrm{A}$ /strip for about $90 \mathrm{kVh}$ in an Ettan IPGphor (GE Healthcare). After IEF, strips were equilibrated by gentle stirring for $15 \mathrm{~min}$ in an equilibration buffer [100 mM Tris- $\mathrm{HCl}$ pH 6.8, $7 \mathrm{M}$ urea, $2 \mathrm{M}$ thiourea, 30\% (w/v) glycerol, 2\% (w/v) SDS] added with $0.5 \%(\mathrm{w} / \mathrm{v})$ DTT for disulfide bridges reduction and for an additional $15 \mathrm{~min}$ in the same equilibration buffer to which $0.002 \%(\mathrm{w} / \mathrm{v})$ bromophenol blue and $4.5 \% \mathrm{w} / \mathrm{v}$ iodoacetamide for cysteine alkylation were added. Second-dimensional SDS-PAGE [93] was run in 12.5\% acrylamide gels using the ETTAN DALT six apparatus (GE Healthcare). Running was first conducted at $5 \mathrm{~W} /$ gel for $30 \mathrm{~min}$ followed by $15 \mathrm{~W} /$ gel until the bromophenol blue line ran off. Two replicates were produced for each biological replicate, thus obtaining six gels per condition $(n=6)$.

Proteins were stained using the colloidal Coomassie Brilliant Blue G-250 ( $\mathrm{CCBB}$ ) procedure, as previously described by Neuhoff and co-workers [94]. The gels were scanned in an Epson Expression 1680 Pro Scanner and analyzed with ImageMaster 2-D Platinum Software (GE Healthcare). Automatic matching was complemented by manual matching. The molecular weights of the spots were deduced on the basis of the migration of SigmaMark$\mathrm{ers}^{\mathrm{TM}}$ wide range (MW 6.500 - 205.000), while pIs were determined according to the strip manufacturer's instructions (GE Healthcare) reporting on the reference gel of the software-assisted analysis the values of $\mathrm{pI}$ predicted for any given length of the strip. Both $\mathrm{M}_{\mathrm{r}}$ and $\mathrm{pI}$ of the spots of interest were then determined by using software-automated algorithm.

Relative spot volumes (\%Vol) of the six replicate gels per condition were compared and were analyzed according to the Student's t-test to verify whether the changes were statistically significant $(p<0.05)$. This analysis was performed by using SigmaStat software. Only spots showing at least a two-fold change in their relative volumes were considered for successive analyses.

\section{Protein in-gel digestion and LC-ESI-MSIMS analysis}

Spots excised from gels stained with CCBB were digested as described by Magni and co-workers [95] with some refine- 
ments. In detail, after the destaining procedure, spots were dried under vacuum on a centrifugal evaporator and incubated in $10 \mathrm{mM}$ DTT, $100 \mathrm{mM} \mathrm{NH}_{4} \mathrm{HCO}_{3}$ for $45 \mathrm{~min}$ at $56^{\circ} \mathrm{C}$. The solution was replaced with $55 \mathrm{mM}$ iodoacetamide, $100 \mathrm{mM} \mathrm{NH}_{4} \mathrm{HCO}_{3}$ and the spots were incubated for $30 \mathrm{~min}$ in the dark at room temperature. After that, spots were briefly washed with $100 \mathrm{mM} \mathrm{NH}_{4} \mathrm{HCO}_{3}$ and again incubated for $15 \mathrm{~min}$ in $50 \%(\mathrm{v} / \mathrm{v})$ acetonitrile (ACN), for $3 \mathrm{~min}$ in $100 \% \mathrm{ACN}$, for $3 \mathrm{~min}$ in $100 \mathrm{mM}$ $\mathrm{NH}_{4} \mathrm{HCO}_{3}$, for $15 \mathrm{~min}$ in $50 \mathrm{mM} \mathrm{NH} \mathrm{HCO}_{3}$ in $50 \%$ (v/v) ACN and finally dried under vacuum. The following phases consisting in the protein digestion with trypsin [Sequencing grade modified Trypsin V5111, Promega, Madison] and in the recovery of peptides were carried out as described in the article above cited.

The LC-ESI-MS/MS experiments were conducted using a Surveyor (MS pump Plus) HPLC system directly connected to the ESI source of a Finnigan LCQ DECA XP MAX ion trap mass spectrometer (ThermoFisher Scientific Inc., Waltham, USA). Chromatography separations were obtained on a BioBasic C18 column $(180 \mu \mathrm{m}$ I.D $\times 150$ $\mathrm{mm}$ length, $5 \mu \mathrm{m}$ particle size), using a linear gradient from $5 \%$ to $80 \%$ solvent B [solvent A: $0.1 \%(\mathrm{v} / \mathrm{v})$ formic acid; solvent B: ACN containing $0.1 \%(\mathrm{v} / \mathrm{v}$ ) formic acid] with a flow of $2.5 \mu \mathrm{l} / \mathrm{min}$. ESI was performed in positive ionization mode with spray voltage and capillary temperature set at $3 \mathrm{kV}$ and at $220^{\circ} \mathrm{C}$, respectively. Data were collected in the full-scan and data dependent MS/MS mode with collision energy of $35 \%$ and a dynamic exclusion window of $3 \mathrm{~min}$.

Spectra were searched by TurboSEQUEST ${ }^{\circledast}$ incorporated in BioworksBrowser 3.2 software (ThermoFisher Scientific Inc., Waltham, USA) against the Zea mays protein subset, Zea mays EST subset and against the protein NCBI-nr database, all downloaded from the National Center for Biotechnology Information [96]. The searches were carried out assuming parent ion and fragment ion mass tolerance of $\pm 2 \mathrm{Da}$ and $\pm 1 \mathrm{Da}$, respectively, two possible missed cleavages per peptide, fixed carboxyamidomethylation of cysteine and variable methionine oxidation. Positive hits were filtered on the basis of peptides scores [Xcorr $\geq 1.5$ ( +1 charge state), $\geq 2.0$ ( +2 charge state),$\geq 2.5$ ( $\geq 3$ charge state), $\Delta \mathrm{Cn} \geq 0.1$, peptide probability $<1 \times 10^{-3}$ and $\mathrm{Sf} \geq$ 0.70 ] [97]. If needed, identified peptides were used in protein similarity search performed by alignment analyses against the NCBI-nr database using the FASTS algorithm [98]. Physical properties of the characterized proteins were predicted by in silico tools at ExPASy [99].

\section{Authors' contributions}

BP contributed to the conception of the experimental design, carried out the determination of biochemical and physiological parameters, protein extraction, 2-DE, pro- tein characterization by LC-ESI-MS/MS and analyzed the MS data, participated in writing the methods section of the manuscript. ASN analyzed the gels and performed statistical analyses. PP measured fluorescence parameters. $\mathrm{MC}$ contributed to the interpretation of the results and took part in the critical revision of the manuscript. LE conceived the study, coordinated the experiments, participated to the determination of biochemical and physiological parameters, wrote and edited the manuscript. All authors read and approved the final manuscript.

\section{Additional material}

\section{Additional file 1 \\ Pictures of the plants. File shows the pictures of the experimental plant material at the different sampling times. \\ Click here for file \\ [http://www.biomedcentral.com/content/supplementary/1471- 2229-9-113-S1.pdf]}

\section{Additional file 2}

Caption of Additional file 3. Caption and legend of Additional file 3. Click here for file

[http://www.biomedcentral.com/content/supplementary/14712229-9-113-S2.doc]

\section{Additional file 3}

Data on protein identification by LC-ESI-MS/MS and bioinformatic analysis. Table shows the sequence of the peptides identified by MS/MS and the statistical information related to peptides, proteins and alignment analyses

Click here for file

[http://www.biomedcentral.com/content/supplementary/14712229-9-113-S3.xls]

\section{Additional file 4}

Details of the protein sequences assigned to spot 53. File shows in detail the sequences of the PEPCase and UB proteins that were identified analyzing the spot 53 by LC-ESI-MS/MS, as well as the sequence alignment analysis to verify the presence of the domain involved in monoubiquitination of the enzyme.

Click here for file

[http://www.biomedcentral.com/content/supplementary/14712229-9-113-S4.doc]

\section{Acknowledgements}

This work was supported by grants from the Italian Ministry of Education, University and Research (MIUR-PRIN 2007). The authors wish to thank Dr. Chiara Fedeli for her valuable contribution during the writing of this manuscript.

\section{References}

I. Marschner H: Mineral Nutrition of Higher Plants London: Academic Press Limited; 1995.

2. Barker AV, Bryson GM: Nitrogen. In Handbook of Plant nutrition Edited by: Barker AV, Pilbeam DJ. Boca Raton: CRC Press; 2007:21-50. 
3. Stitt M: Nitrate regulation of metabolism and growth. Curr Opin Plant Biol 1999, 2:178-186.

4. Brouquisse R, Masclaux C, Feller U, Raymond P: Protein hydrolysis and nitrogen remobilisation in plant life and senescence. In Plant Nitrogen Edited by: Lea PJ, Morot-Gaudry JF. Hidelberg: SpringerVerlag Berlin Hidelberg; 200 I:275-293.

5. Stitt M, Müller C, Matt P, Gibon Y, Carillo P, Morcuende R, Sheible WR, Krapp A: Steps towards an integrated view of nitrogen metabolism. J Exp Bot 2002, 53:959-970.

6. Miller AJ, Cramer MD: Root nitrogen acquisition and assimilation. Plant Soil 2004, 274: I-36.

7. Scheible WR, Morcuende R, Czechowski T, Fritz C, Osuna D, Palacios-Rojas N, Schindelasch D, Thimm O, Udvardi MK, Stitt M: Genome-wide programming of primary and secondary metabolism, protein synthesis, cellular growth processes, and the regulatory infrastructure of Arabidopsis in response to nitrogen. Plant Physiol 2004, 136:2483-2499.

8. Jackson LE, Burger M, Cavagnaro TR: Roots, nitrogen transformation and ecosystem services. Annu Rev Plant Biol 2008, 59:34I-63.

9. Lawlor DW, Lemaire G, Gastal F: Nitrogen, plant growth and crop yield. In Plant Nitrogen Edited by: Lea PJ, Morot-Gaudry JF. Hidelberg: Springer-Verlag Berlin Hidelberg; 2001:343-367.

10. Hirel B, Bertin P, Quillere I, Bourdoncle W, Attagnant C, Dellay C Gouy A, Cadiou S, Retailliau C, Falque M, Gallais A: Towards a better understanding of the genetic and physiological basis for nitrogen use efficiency in maize. Plant Physiol 200I, 125: $1258-1270$.

II. Hagedorn F, Bucher JB, Schleppi P: Contrasting dynamics of dissolved inorganic and organic nitrogen in soil and surface waters of forested catchments with Gleysols. Geoderma 200I, 100:173-192.

12. Owen AG, Jones DL: Competition for amino acids between wheat roots and rhizosphere microorganisms and the role of amino acids in plant $\mathbf{N}$ acquisition. Soil Biol Biochem 200I, 33:65I-657.

13. Orsel M, Filleur S, Fraisier V, Daniel-Vedele F: Nitrate transport in Plants: which gene and which control? J Exp Bot 2002, 53:825-833.

14. Ullrich $\mathrm{Cl}$, Novacky AJ: Extra and intracellular $\mathbf{p H}$ and membrane potential changes by $\mathrm{K}^{+}, \mathrm{Cl}, \mathrm{H}_{2} \mathrm{PO}_{4}$ and $\mathrm{NO}_{3}$ uptake and fusicoccin in root hairs of Limnobium stoloniferum . Plant Physiol 1990, 94:156I-1567.

15. McClure PR, Kochian LV, Spanwick RM, Shaff JE: Evidence for cotransport of nitrate and protons in maize roots. I. Effects of nitrate on the membrane potential. Plant Physiol 1990, 93:28I-289.

16. Meharg AA, Blatt MR: $\mathrm{NO}_{3}^{-}$transport across the plasma membrane of Arabidopsis thaliana root hairs: kinetic control by $\mathrm{pH}$ and membrane voltage. J Membrane Biol 1995, 145:49-66.

17. Crawford NM, Glass ADM: Molecular and physiological aspects of nitrate uptake in plants. Trends Plant Sci 1998, 3:389-395.

18. Huang NC, Liu KH, Lo HJ, Tsay YF: Cloning and functional characterization of an Arabidopsis nitrate transporter gene that encodes a constitutive component of low-affinity uptake. Plant Cell 1999, I I: |38I-I392.

19. Espen L, Nocito FF, Cocucci M: Effect of $\mathrm{NO}_{3}^{-}$transport and reduction on intracellular $\mathrm{pH}$ : an in vivo NMR study in maize roots. J Exp Bot 2004, 55:2053-206I.

20. Palmgren MG: Plant plasma membrane $\mathbf{H}^{+}$-ATPases: powerhouses for nutrient uptake. Annu Rev Plant Physiol Plant Mol Biol 200I, 52:8I7-845.

21. Santi S, Locci G, Monte R, Pinton R, Varanini Z: Induction of nitrate uptake in maize roots: expression of putative high affinity nitrate transporter and plasma membrane $\mathrm{H}^{+}$-ATPase isoforms. J Exp Bot 2003, 54:185I-I864.

22. Sondergaard TE, Schulz A, Palmgren MG: Energization of transport processes in plants. roles of the plasma membrane $\mathrm{HI}$ ATPase. Plant Physiol 2004, 1 36:2475-2482.

23. Oaks A, Hirel B: Nitrogen metabolism in roots. Annu Rev Plant Physiol 1985, 36:345-365.

24. Meyer C, Stitt M: Nitrate reduction and signalling. In Plant Nitrogen Edited by: Lea PJ, Morot-Gaudry JF. Hidelberg: Springer-Verlag Berlin Hidelberg; 2001:37-59.
25. Hirel B, Lea PJ: Ammonia assimilation. In Plant Nitrogen Edited by: Lea PJ, Morot-Gaudry JF. Hidelberg: Springer-Verlag Berlin Hidelberg; 2001:79-99.

26. Crawford NM: Nitrate: nutrient and signal for plant growth Plant Cell 1995, 7:859-868.

27. Paul MJ, Foyer $\mathrm{CH}$ : Sink regulation of photosynthesis. J Exp Bot 200I, 52: I383-|400.

28. Forde BG: Local and long-range signalling pathways regulating plant responses to nitrate. Annu Rev Plant Biol 2002, 53:203-224.

29. Wang R, Guegler K, LaBrie ST, Crawford NM: Genomic analysis of a nutrient response in Arabidopsis reveals diverse expression patterns and novel metabolic and potential regulatory genes induced by nitrate. Plant Cell 2000, I 2: | 49|-I509.

30. Rossignol M: Analysis of the plant proteome. Curr Opin Biotech 200I, I 2:13I-I34.

31. Roberts JKM: Proteomics and future generation of plant molecular biologists. Plant Mol Biol 2002, 48: I43-I54.

32. Yarmush ML, Jayaraman A: Advances in proteomic technologies. Annu Rev Biomed Eng 2002, 4:349-373.

33. Patterson SD, Aebersold RH: Proteomics: the first decade and beyond. Nat Genet Suppl 2003, 33(Suppl):3 II-323.

34. Jorrín-Novo JV, Maldonato AM, EchevarríaZomeòo S, Valledor L, Castllejo MA, Curto M, Valero J, Sghaier B, Donoso G, Redonado I: Plant Proteomics update (2007-2008): Second-generation proteomic techniques, an appropriate experimental design, and data analysis to fulfil MIAPE standards, increase plant proteome coverage and expand biological knowledge. J Proteomics 2009, 72:285-3।4.

35. Lawrence CJ, Dong Q, Mary L, Polacco ML, Seigfried TE, Brendel V: MaizeGDB, the community database for maize genetics and genomics. Nucleic Acids Res 2004, 32:D393-D397.

36. Porubleva L, Velden KV, Kothari S, David J, Oliver DJ, Parag R, Chitnis PR: The proteome of maize leaves: Use of gene sequences and expressed sequence tag data for identification of proteins with peptide mass Fingerprints. Electrophoresis 200I, 22: $1724-1738$.

37. Majeran W, Cai Y, Sun Q, van Wijk KJ: Functional differentiation of bundle sheath and mesophyll maize chloroplasts determined by comparative proteomics. Plant Cell 2005, I7:3| II-3| 40 .

38. Dembinsky D, Woll K, Saleem M, Liu Y, Fu Y, Borsuk LA, Lamkemeyer T, Fladerer C, Madlung J, Barbazuk B, Nordheim A, Nettleton $D$, Schnable PS, Hochholdinger F: Transcriptomic and proteomic analyses of pericycle cells of the maize primary root. Plant Physiol 2007, I 45:575-588.

39. Bahrman N, Le Gouls J, Negroni L, Amilhat L, Leroy P, Lainé AL, Jaminon $O$ : Differential protein expression assessed by twodimensional gel electrophoresis for two wheat varieties grown at four nitrogen levels. Proteomics 2004, 4:709-7I9.

40. Bahrman N, Gouy A, Devienne-Barret F, Hirel B, Vedele F, Le Gouis $\mathrm{J}$ : Differential change in root protein pattern of two wheat varieties under high and low nitrogen nutrition levels. Plant Sci 2005, 168:8I-87.

41. Foyer CH, Ferrario-Méry S, Noctor G: Interactions between carbon and nitrogen metabolism. In Plant Nitrogen Edited by: Lea PJ, Morot-Gaudry JF. Hidelberg: Springer-Verlag Berlin Hidelberg; 200I:237-254.

42. Sivasankar S, Rothstein S, Oaks A: Regulation of the accumulation and reduction of nitrate by nitrogen and carbon metabolites in maize seedlings. Plant Physiol 1997, I | 4:583-589.

43. Klein D, Morcuende R, Stitt M, Krapp A: Regulation of nitrate reductase expression in leaves by nitrate and nitrogen metabolism is completely overridden when sugars fall below a critical level. Plant Cell Environ 2000, 23:863-87I.

44. Huppe HC, Turpin DH: Appearance of novel glucose-6-phosphate dehydrogenase isoforms in Chlamydomonas reinhardtii during growth on nitrate. Plant Physiol 1996, I 10:1431-1433.

45. Wang YH, Garvin DF, Kochian LV: Nitrate-induce genes in tomato roots. Array analysis reveals novel genes that may play a role in nitrogen nutrition. Plant Physiol 200I, I 27:345-359.

46. Li M, Villemur R, Hussey PJ, Silflow CD, Gantt JS, Snustad DP: Differential expression of six glutamine synthetase genes in Zea mays. Plant Mol Biol 1993, 23:40 I-407. 
47. Sakakibara H, Kawabata S, Hase T, Sugiyama T: Differential effects of nitrate and light on the expression of glutamine synthetases and ferredoxin-dependent glutamate synthase in maize. Plant Cell Physiol 1992, 33: I193-II98.

48. Rockel P, Strube F, Rockel A, Wildt J, Kaiser WM: Regulation of nitric oxide (NO) production by plant nitrate reductase in vivo and in vitro. J Exp Bot 2002, 53:103-110.

49. Igamberdiev AU, Bycova NV, Hill RD: Nitric oxide scavenging by barley hemoglobin is facilitated by a monodehydroascorbate reductase-mediated ascorbate reduction of methemoglobin. Planta 2006, 223: 1033-1040.

50. Lamattina L, Garcia-Mata C, Pagnussat G: Nitric oxide: the versatility of an extensive signal molecule. Annu Rev Plant Biol 2003, 54:109-136.

5I. Stöhr C, Stremlau S: Formation and possible roles of nitric oxide in plant roots. J Exp Bot 2006, 57:463-470.

52. Zhao DY, Tian QY, Li LH, Zhang WH: Nitric oxide is involved in nitrate-induced inhibition of root elongation in Zea mays Ann Bot 2007, 100:497-503.

53. Peschke VM, Sachs MM: Characterization and expression of transcripts induced by oxygen deprivation in maize (Zea mays L.). Plant Physiol 1994, 104:387-394.

54. Igamberdiev AU, Hill RD: Nitrate NO and haemoglobin in plant adaptation to hypoxia: an alternative to classic fermentation pathways. J Exp Bot 2004, 408:2473-2482.

55. Fritz C, Palacios-Rojas N, Fell R, Stitt M: Regulation of secondary metabolism by the carbon-nitrogen status in tobacco: nitrate inhibits large sectors of phenylpropanoid metabolism. Plant J 2006, 46:533-548.

56. Kingston-Smith AH, Bollard AL, Minchin FR: Stress-induced changes in protease composition are determined by nitrogen supply in non-nodulating white clover. J Exp Bot 2005, 56:745-753.

57. Simões I, Faro C: Structure and function of plant aspartic proteinases. Eur J Biochem 2004, 27 I:2067-2075.

58. Askura T, Watanabe H, Abe K, Arai S: Rice aspartic proteinases, oryzasin, expressed during seed ripening and germination, has a gene organization distinct from those of animal and microbial aspartic proteinases. Eur J Biochem 1995, 232:77-83.

59. Raven JA: Biochemical disposal of excess $\mathbf{H}^{+}$in growing plants? New Phytol 1986, I 04: 175-206.

60. Sakano K: Revision of biochemical pH-stat: involvement of alternative pathway metabolisms. Plant Cell Physiol 1998 39:467-473.

61. Britto DT, Kronzucker HJ: Nitrogen acquisition, PEP carboxylase, and cellular pH homeostasis: new views on old paradigms. Plant Cell Environ 2005, 28: |396-|409.

62. Uhrig RG, She YM, Leach CA, Plaxton WC: Regulatory monoubiq uitination of phosphoenolpyruvate carboxylase in germinating castor oil seeds. JBC 2008, 283:29650-29657.

63. de Vetten NC, Ferl RJ: Two genes encoding GF I 4 ( I 4-3-3) proteins in Zea mays. Structure, expression, and potential regulation by G-box-binding complex. Plant Physiol 1994, 106: 1593-1604

64. Bihn EA, Paul AL, Wang SW, Erdos GW, Ferl RJ: Localization of I43-3 proteins in the nuclei of Arabidopsis and maize. Plant 1997, I 2: | 439-|445.

65. Roberts MR: Regulatory 14-3-3 protein-protein interactions in plant cells. Curr Opin Plant Biol 2000, 3:400-405.

66. Bachmann M, Huber JL, Athwal GS, Wu K, Ferl RJ, Huber SC: I4-33 proteins associate with the regulatory phosphorylation site of spinach leaf nitrate reductase in an isoform-specific manner and reduce dephosphorylation of Ser-543 by endogenous protein phosphatases. FEBS Lett 1996, 398:26-30.

67. Ikeda Y, Koizumi N, Kusano T, Sano H: Specific binding of a 14-33 protein to autophosphorylated WPK4, an SNFI-related wheat protein kinase, and to WPK-4-phosphorylated nitrate reductase. JBC 2000, 275:31695-31700.

68. Dickson R, Weiss C, Howard RJ, Alldrick SP, Ellis RJ, Lorimer G, Azem A, Viitenen PV: Reconstitution of higher plant chloroplast chaperonin 60 tetradecamers active in protein folding. JBC 2000, 275: I|829-I|835.

69. Averill RH, Bailey-Serres J, Kruger NJ: Co-operation between cytosolic and plastidic oxidative pentose phosphate pathways revealed by 6-phosphogluconate dehydrogenase-deficient genotypes of maize. Plant J 1998, 14:449-457.
70. Malkin R, Niyogi K: Photosynthesis. In Biochemistry and Molecular Biology of Plants Edited by: Buchanan B, Gruissem W, Jones R. American Society of Plant Physiologists Rockville; 2000:568-628.

7I. Rapala-Kozik M, Kowalaska E, Ostrowska K: Modulation of thiamine metabolism in Zea mays seedlings under conditions of abiotic stress. J Exp Bot 2008, 59:4I 33-4I43.

72. Edwards GE, Franceschi VR, Voznesenskaya EV: Single-cell $\mathbf{C}_{4}$ phothosynthesis versus the dual-cell (Kranz) paradigm. Annu Rev Plant Biol 2004, 55: I73-196.

73. Ueno Y, Imanari E, Emura J, Yoshizawa-Kumagaye K, Nakajiama K, Inami K, Shiba T, Sakakibara H, Sugiyama T, Izui K: Immunological analysis of the phosphorylation state of maize C4-form phosphoenolpyruvate carboxylase with specific antibodies raised against a synthetic phosphorylated peptide. Plant J 2000, 2|:|7-26.

74. Izui K, Matsumura H, Furumoto T, Kai Y: Phosphoenolpyruvate carboxylase: a new era of structural biology. Annu Rev Plant Biol 2004, 55:69-84

75. Nemchenko A, Kunze S, Feussner I, Kolomietes M: Duplicate maize I3-lipoxygenase genes are differentially regulated by circadian rhythm, cold stress, wounding, pathogen infection, and hormonal treatments. J Exp Bot 2006, 57:3767-3779.

76. Feussner I, Bachmann A, Höhne $M$, Kind $\mathrm{H}$ : All three acyl moieties of trilinolein are efficiently oxygenated by recombinant His-tagged lipid body lipoxygenase in vitro. FEBS Lett 1998 , $431: 433-436$.

77. James HE, Robinson C: Nucleotide sequence of cDNA encoding the precursor of the $23 \mathrm{kDa}$ protein of the photosynthetic oxygen-evolving complex from wheat. Plant Mol Biol 199I, I7:179-182

78. Yoshiba Y, Yamaguchi-Shinozaki K, Shinozaki K, Harada Y: Characterization of a cDNA clone encoding $23 \mathrm{kDa}$ polypeptide of the oxygen-evolving complex of photosystem II in rice. Plant Cell Physiol 1995, 36:1677-1682

79. Sourosa M, Aro EM: Expression, assembly and auxiliary functions of photosystem II oxygen-evolving proteins in higher plants. Photosynth Res 2007, 93:89-100.

80. Ifuku K, Yamamoto Y, Ono T, Ishihara S, Sato F: PsbP protein, but not PsbQ protein, is essential for the regulation and stabilization of photosystem II in higher plants. Plant Physiol 2005 , | 39: | |75-| | 84

8I. Gaude N, Bréhélin C, Tischendorf G, Kessler F, Dörmann P: Nitrogen deficiency in Arabidopsis affects galactolipid composition and gene expression and results in accumulation of fatty acid phytyl esters. Plant I 2007, 49:729-739.

82. Sakurai I, Mizusawa N, Wada H, Sato N: Digalactosyldiacylglycerol is required for stabilization of the oxygen-evolving complex in photosystem II. Plant Physiol 2007, | 45: | 36 |- | 370.

83. Cataldo DA, Haroon M, Schrader LE, Youngs VL: Rapid colorimetric determination of nitrate in plant tissue by nitration of salicylic acid. Commun Soil Sci Plant Anal 1975, 6:71-80.

84. Ferrario-Méry $\mathrm{S}$, Valadier $\mathrm{MH}$, Foyer $\mathrm{CH}$ : Overexpression of nitrate reductase in tobacco delays drought-induced decreases in nitrate reductase activity and mRNA. Plant Physiol 1998, I I 7:293-302.

85. Nelson NA: A photometric adaptation of the Somogy method for the determination of glucose. JBC 1944, I 53:375-384.

86. Moore $\mathrm{S}$, Stein $\mathrm{WH}$ : A modified ninhydrin reagent for the photometric determination of amino acids and related compounds. JBC 1954, 2 I I:907-913.

87. Martínez-Garcia JF, Monte E, Quall PH: A simple, rapid and quantitative method for preparing Arabidopsis protein extracts for immunoblot analysis. Plant J 1999, 20:25I-257.

88. Lichtenthaler HK: Chlorophylls and carotenoids: Pigments of photosynthetic biomembranes. Met Enzymol 1987, I 48:350-382.

89. Heat RL, Packer K: Photoperoxidation in isolated chloroplasts. I. Kinetics and stoichiometry of fatty acid peroxidation. Arch Biochem Biophys 1968, I25:189-198.

90. Krause $\mathrm{GH}$, Weis E: Chlorophyll fluorescence and photosynthesis: the basics. Annu Rev Plant Physiol Plant Mol Biol I991, 42:313-349

91. Genty B, Briantais JM, Baker NR: The relationship between the quantum yield of photosynthetic electron transport and quenching of chlorophyll fluorescence. BBA I989, 990:87-92. 
92. Hurkman WJ, Tanaka CK: Solubilization of plant membrane proteins for analysis by two-dimensional gel electrophoresis. Plant Physiol 1 986, 81:802-806.

93. Laemmli UK: Cleavage of structural proteins during the assembly of the head of bacteriophage. T4. Nature 1970, 227:680-685.

94. Neuhoff $\mathrm{V}$, Arold N, Taube D, Ehrhardt W: Improved staining of proteins in polyacrylamide gels including isoelectric focusing gels with clear background at nanogram sensitivity using Coomassie Brilliant Blue G-250 and R-250. Electrophoresis 1988, 9:255-262.

95. Magni C, Scarafoni A, Herndl A, Sessa F, Prinsi B, Espen L, Duranti M: Combined electrophoretic approaches for the study of white lupin mature seed storage proteome. Phytochemistry 2007, 68:997-1007.

96. National Center for Biotechnology Information [http:// www.ncbi.nlm.nih.gov/]

97. Eng JK, McCormack AL, Yates JR III: An approach to correlate tandem mass spectral data of peptides with amino acid sequences in a protein database. J Am Soc Mass Spectrom 1994, 5:976-989.

98. Mackey AJ, Haystead TAJ, Pearson WR: Getting more from less: algorithms for rapid protein identification with multiple short peptide sequences. Mol Cell Proteomics 2002, I:I39-I47.

99. ExPASy Proteomics Server [http://www.expasy.org/]

Publish with Bio Med Central and every scientist can read your work free of charge

"BioMed Central will be the most significant development for disseminating the results of biomedical research in our lifetime. "

Sir Paul Nurse, Cancer Research UK

Your research papers will be:

- available free of charge to the entire biomedical community

- peer reviewed and published immediately upon acceptance

- cited in PubMed and archived on PubMed Central

- yours - you keep the copyright 